Primljen / Received: 02.04.2021 Ispravljen / Corrected: 25.5.2021.

Prihvaćen / Accepted: 24.6.2021.

Dostupno online / Available online: 10.8.2021.
Bridge failures, forensic structural engineering and recommendations for design of robust structures

Authors:

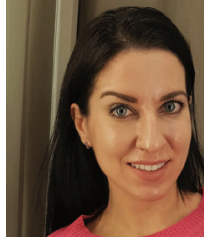

Ivana Milić, MCE

Trames d.o.o.

Ivana.milic211@gmail.com

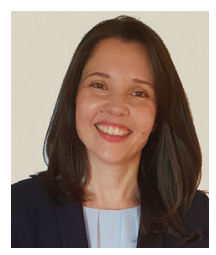

Prof. Ana Mandić Ivanković, PhD. CE University of Zagreb

Faculty of Civil Engineering

ana.mandic.ivankovic@grad.unizg.hr

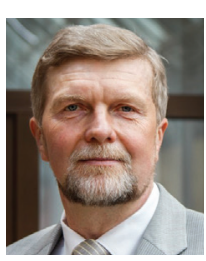

Anton Syrkov, PhD. CE

Transmost PLC, Russia

syrkov_av@transmost.ru

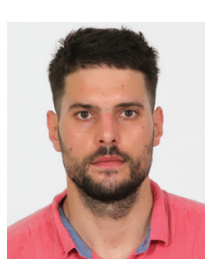

Dominik Skokandić, PhD. CE

University of Zagreb

Faculty of Civil Engineering

dominik.skokandic@grad.unizg.hr

Corresponding author
Ivana Milić, Ana Mandić Ivanković, Anton Syrkov, Dominik Skokandić

Subject review

\section{Bridge failures, forensic structural engineering and recommendations for design of robust structures}

A review of forensic structural engineering, which is a strategy that follows after bridge failure, is presented in the paper. A detailed statistical analysis, and worldwide systematisation of available bridge failure data for the 1966-2020 period, are given. More than six hundred cases of partial or full collapse of bridges are analysed in detail, and causes that have led to their failure are examined. Failure of each of these bridges was in most cases not caused by a single factor, i.e. the main cause was most often just a trigger in the cause-and-effect sequence of events that contributed to such failure. Consequently, in addition to main causes, the influence of human factor, as a precondition leading to failure, is considered in each of the analysed cases. Types of progressive collapse, being a critical structural failure mechanism, are described in the second part of the paper, with an emphasis on bridges. An overview of the theory of structural robustness is also given. Design guidelines and approaches, aimed at preventing catastrophic failure and creating more robust structures, are presented. Methods for achieving robustness in the design of new bridges and in the strengthening of the existing ones are also described, and practical real-life examples are provided.

Key words:

forensic engineering, bridge failure, progressive collapse, robustness, extreme actions

Pregledni rad

Ivana Milić, Ana Mandić Ivanković, Anton Syrkov, Dominik Skokandić

\section{Otkazivanje mostova, forenzičko inženjerstvo i preporuke za projektiranje robusnih konstrukcija}

U radu je dan pregled forenzičkog inženjerstva u građevinarstvu, strategije koja slijedi nakon otkazivanja mostova. Provedena je statistička analiza i sistematizacija raspoloživih podataka o otkazivanjima mostova u cijelom svijetu u vremenskom razdoblju od 1966. 2020. godine. Detaljno je analizirano više od 600 slučajeva djelomičnog ili potpunog rušenja mostova te su analizirani uzroci koji su doveli do njihovog otkazivanja. Do otkazivanja svakog od ovih mostova najčešće nije došlo uslijed samo jednog faktora, već je glavni uzrok je najčešce okidač u uzročnoposljedičnom slijedu niza događaja koji su tome pridonijeli. Sukladno tome, osim glavnih uzroka, za svaki od analiziranih slučajeva naveden je i utjecaj ljudskog faktora kao preduvjeta koji je doveo do otkazivanja. U drugom dijelu rada opisani su tipovi progresivnog kolapsa kao kritičnog načina otkazivanja konstrukcija, s naglaskom na mostove, kao i pregled teorije robusnosti konstrukcija. Dane su smjernice i pristupi projektiranju u cilju sprječavanja katastrofalnih otkazivanja i stvaranja robusnijih konstrukcija. Opisani su načini postizanja robusnosti kod projektiranja novih te ojačavanja postojećih mostova, uz praktične primjere iz prakse.

Ključne riječi:

forenzičko inženjerstvo, otkazivanje mostova, progresivni kolaps, robusnost, izvanredna djelovanja 


\section{Introduction}

Road and railway bridges are complex structural systems, and their design and construction process require a high level of knowledge, expertise, and experience. Procedures for bridge design, construction and maintenance are defined in Croatia with a set of design codes and guidelines, and their successful and proper application guarantees durability and safety of bridges throughout their anticipated service life. Due to their long service life and important role as a critical part of transport infrastructure, and considering an increase in the volume of traffic in the last decades, structural requirements have continuously been increasing for both new and existing bridges. For example, environmental requirements for the existing bridges have been changing over their service life, the traffic is increasing (by volume and vehicle weight) as a result of urbanization, and overall transport needs of the society are constantly on the rise. Despite the high level of expertise and experience of engineers, continuous development of new knowledge, implementation of new technologies and improvement of current design codes, we are still witnessing bridge failure accidents with catastrophic consequences in all parts of the world.

Due to their importance and long service, each bridge failure raises many questions regarding technical and/or legal indicators, and involves the issue of accountability for the damage caused. In these situations, the answer is provided by forensic structural engineering, which is an applied science focusing on the determination of causes of structural failure.

This paper provides a review of the use of forensic engineering in civil and structural engineering, and discusses main reasons for bridge failures, along with the corresponding human factors, based on the available bridge failure database. An overview of progressive collapse of the existing and new structures is given in the second part of the paper, where structural robustness issues are also discussed.

\section{Forensic Engineering}

\subsection{Overview}

Forensic engineering is a multidisciplinary scientific area with applications in various technical fields. According to NAFE (National Academy of Forensic Engineers), a USA association of forensic engineers in all technical fields "Forensic Engineering is the application of the art and science of engineering in the matters which are in, or may possibly relate to, the jurisprudence system, inclusive of alternative dispute resolution" [1]. The ASCE (American Society of Civil Engineers) provides a broader definition: "Forensic engineering is the application of engineering principles to the investigation of failures or other performance problems. Forensic engineering also involves testimony on the findings of these investigations before a court of law" [2]. A similar definition is provided in the [3]: "Forensic engineering can be classified as a technical discipline or more precisely as one of the applied technical sciences where the main focus is on investigating the causes, the course and consequences of negative technical phenomena in various fields."
At the moment, there is no official society of forensic structural engineers in Europe. However, the international association of structural engineers IABSE (International Association for Bridges and Structural Engineering) formed a working group in 2011, called Forensic Structural Engineering, whose main objective is the improvement and practical application of forensic structural engineering. As a part of the working group activities, a survey of practical application of forensic engineering was conducted in several European countries and the USA [4]. Based on the survey results, the working group report stated that in the majority of included countries (except the UK and the USA) there are no official associations of forensic structural engineers, and no legal regulations for the investigation of structural failures. However, all countries involved in the survey do have some form of unofficial guidelines for forensic engineers. Furthermore, it was concluded that the professional responsibility of engineers in charge of design, construction and/or maintenance varies greatly from country to country. It is important to note that this report [4] took into account only handful of European countries and that the working group was not able to access country based databases on bridge failures and consequences.

Overall, forensic engineering can be described as an interdisciplinary scientific field, dealing with the investigation of technical illegalities and their legal aspects. Civil engineers work in ever-changing environments and so their activities are burdened with a number of unknown factors and uncertainties. Therefore, civil engineering is subjected to impacts of various technical irregularities with severe consequences, which is due to a complex process of design and construction, long service life of gradually deteriorating structures, need for a large number of various experts in different design phases, and variabilities that are an integral part of the overall process.

During the life cycle of structures, including the design and construction process, there are a number of factors that influence the structure itself that cannot be defined with absolute certainty. Therefore, it can be concluded that the structure design process should be based on reliability engineering, with current design standards providing the basic technical framework. According to [5]: "As long as structures and products are designed, built, and manufactured by humans using imperfect materials and procedures, failures will be experienced along with successes."

The reason for the investigation of structural failures can be twofold. On the one hand, the investigation is focused on safety, improvements in structural systems, and prevention of future failures while, on the other hand, investigation results can be used for establishing responsibilities for specific failure [6]. Although guidelines for the conduct of forensic structural investigations are not available in many countries [6], there are some countries in which such strategies are properly defined, as given in [7-9].

Although the forensic investigation process of structural failure is reversible when compared to the design process for new structures, the forensic structural engineer is required to know both current and past design standards, construction technology and methodology, behaviour of structures, and must be able to anticipate the situations and events that could potentially cause structural failure. Design standards according to which a specific 
structure was designed and built, provide a starting point for the investigation, as they represent the minimum level of structural reliability which the structure is required to fulfil [10]. In addition to technical competencies, a successful forensic structural engineer should possess certain communications and analytical skills, and must be socially and professionally accountable. Furthermore, a forensic structural engineer is required to have a "detective" mindset, with an eye for details, and must be capable of thinking outside the box. The competencies of a successful forensic structural engineer are presented in Figure 1, although it should be noted that these qualities are expected from all engineers included in the design, construction and maintenance of structures.

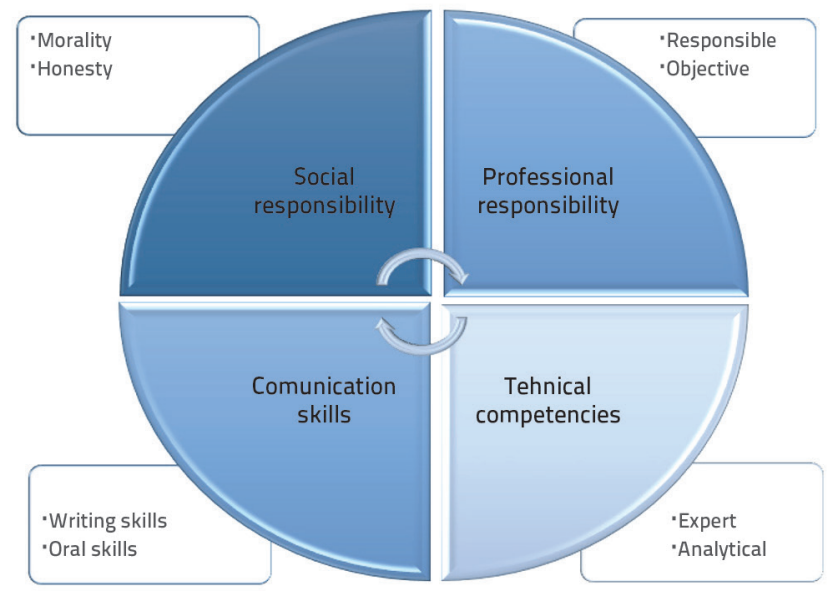

Figure 1. Competencies of engineers

In cases when structural failure results in large losses in terms of property value and/or human lives, the responsibility and compensation for the losses are often determined through legal means, in which cases forensic engineers act as expert witnesses. In such situations, forensic engineer is required to be familiar with legal aspects and procedures. It is important to note that a forensic engineer cannot act as an expert witness before being formally acknowledged and accepted by a competent court [11]. According to the ASCE's Code of Ethics [12]: "Engineers should express professional opinions truthfully and only when founded on adequate knowledge and honest conviction". Legal practice in the USA (the United States of America) does not require that the expert witness opinion be absolutely certain, it only requires that the opinion is based on a "reasonable degree of the engineer's certainty" [10]. Furthermore, in the USA engineers have to meet a "standard of care", defined as [10]: "not what an engineer should have done in someone's opinion, or what someone claims that he or she and/ or others would have done, nor is it what in someone's opinion an engineer would do now but, rather, what normally competent engineers actually did do at the time under similar circumstances."

\subsection{Forensic engineering}

Forensic engineers work in various environments and circumstances, but the investigation process always follows similar steps and procedures. It starts with the gathering of all available pieces of information, their processing and analysis, development of preliminary failure hypothesis, which is followed by engineering analysis and validation of the defined hypothesis. After the reasons leading to structural failure are defined and validated, the second phase of the investigation is the determination of legal, professional, and moral responsibility, which often result in legal procedures. The flowchart of the forensic structural investigation is presented in Figure 2.

The first step after the structural failure occurs is to secure the failure site and to establish crisis management. It is desirable to involve the forensic structural engineer immediately in order to conduct a preliminary visual inspection of the failure site. During the first inspection, a detailed photo documentation of the structure has to be made, and the corresponding damage has to be established. Furthermore, the engineer also uses preliminary inspection for the collection of samples of the built-in materials for subsequent testing.

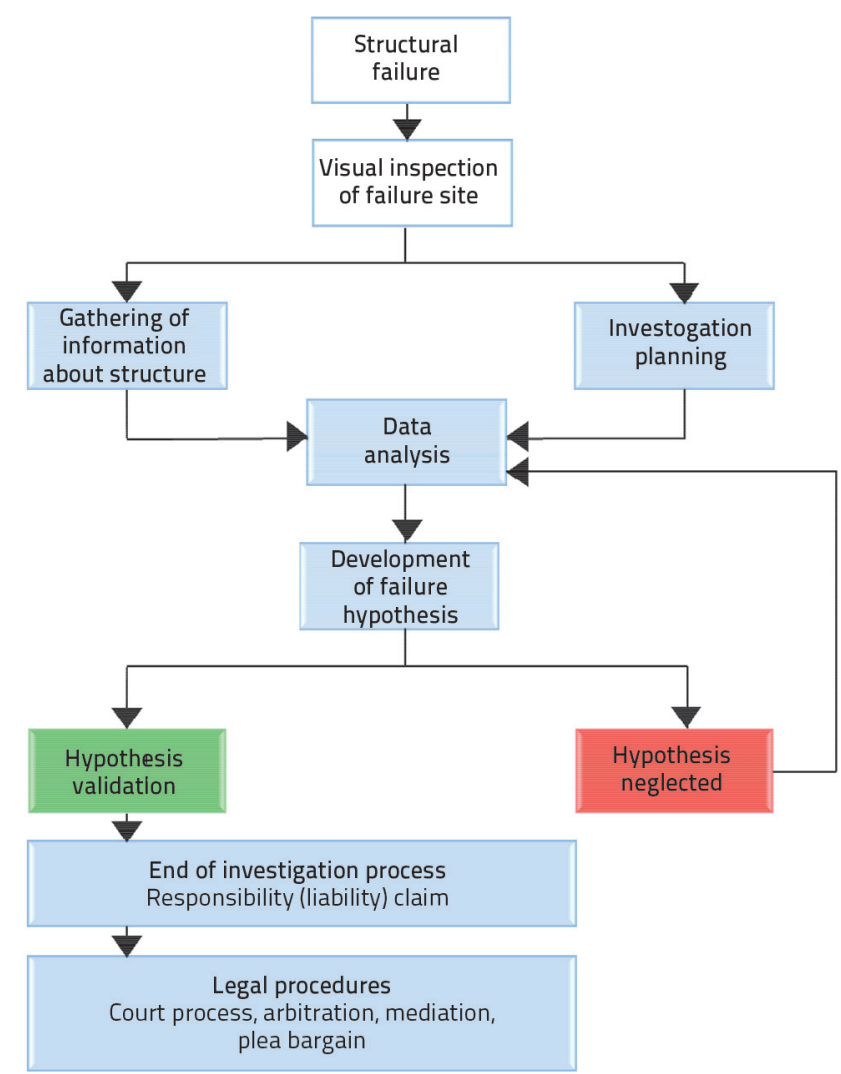

Figure 2. Flowchart of forensic investigation of structural failure

In addition to photo documentation and collection of samples, it is advisable to conduct preliminary interviews with all eyewitnesses to structural failure as soon as possible. During the interview process the interviewees would be asked if they possess any photos/videos of the failure, if they are familiar with the condition of the structure prior to failure, if they have spotted anything unusual, etc. Based on the findings made during the visual inspection, the preliminary assessment is made and a framework for further investigations is established. The next step is to collect all available information on the structure, including the original design documentation, reports submitted by the construction company and supervising engineer, 
and all subsequent documentation in case a reconstruction work was conducted during the service life of the structure. The important part of the documentation are structural maintenance reports, assessment reports, documentation on the built-in material testing, if available. Furthermore, the design standards that were used at the time of the design and construction of the structure should be made available to the forensic engineer so that the responsibilities of all stakeholders can be established. Finally, any information on the extreme weather conditions, extreme loading events, or extraordinary events (e.g., earthquakes) that occurred during the service life of the structure should also be collected.

Investigation planning includes definition of the scope and extent of investigations, creation of a competent investigating team, and clear definition of objectives and compensations. The scope of the investigation work varies based on the extent of failure consequences in terms of loss of property and/or human lives.

The analysis of all gathered information is a viable part of the investigation process. Therefore, the team of experts must take into account all known circumstances of the structural failure and combine them in a causal sequence. This step includes identification and analysis of collected evidence, conduct of experimental testing (in lab or in-situ), and static (and dynamic if required) calculations.

The results obtained by data analysis, experimental testing, and calculations should lead to the definition of the hypothesis about reasons for structural failure. During this process, it is crucial to have as many interdisciplinary opinions as possible, and full use should be made of analytical skills and critical thinking of the expert team, which should all result in an objective conclusion. Once the initial conclusion and hypothesis is defined, the entire investigation procedure has to be reviewed in order to determine whether all required facts have been taken into account. If any oversight or mistake that could influence the causal sequence is noticed during such review, then the investigation should start from the beginning. On the other hand, if the review shows that the investigation has been successful and objective, the hypothesis is validated and the final report on structural failure is compiled. The report contains the principal reason for the structural damage and the sequence of events that resulted in structural failure.

Once the investigation is over, the responsibility for the failure can be determined in the court process, in which case the forensic engineer has the role of an expert witness. The objective of the court process is to determine professional and legal responsibilities, appropriate penalty for the responsible party, and the corresponding compensations for damaged parties. As an alternative to the court process, other legal procedures can be undertaken after forensic investigation, such as mediation, arbitration, off-court settlement, etc [13].

The scope of the investigation should be defined so as to be as broad as possible in order to take into account all potential reasons that could result in structural failure. If the consequences of failure are not too severe, the investigation may be less substantial, which would largely depend on the extent of damage, material and financial losses, and/or losses of human lives. Furthermore, the scope of the investigation also depends on the funding and time period available for all required investigations.
A forensic investigation can be conducted even in cases when structural failure does not occur, or in case of partial failure of structural elements, in order to determine the state of the structure. Furthermore, the investigation in case of complete failure can result in determining more than one cause of structural failure, which is why it is important that the investigation team is composed of interdisciplinary experts.

To summarize forensic structural engineering, it can be described as an interdisciplinary approach that is implemented to determine a causal sequence that results in full or partial structural failure, or simply to identify the state of the structure after an event that was not taken into account during the design and construction process (e.g., an earthquake). Furthermore, the results of forensic investigation provide a basis for legal proceedings (if necessary) and determination of professional and legal responsibilities.

\section{Bridge failure}

\subsection{Introduction}

Structural failure can be defined as [10]: "Nonconformance of the structural system with design expectations" or "Unacceptable difference between intended and actual building performance". It is clear that these definitions take into account all structural deficiencies, ranging from invisible cracks to catastrophic structural failures. It is important to note that the extent of damage or failure does not always correspond to the importance of the lessons that can be learned from the analysis of such events.

Nevertheless, structural failures with catastrophic consequences are the ones that the society remembers the most. One of such events, which occurred due to human error in the design process, is the 1907 Quebec bridge failure that resulted in the death of 75 workers involved at that moment in the construction of this bridge. The investigations showed that the stresses in the bridge superstructure were higher than the ones that were considered acceptable at the time. It was established that the accident was due to the design flaw because the span of the bridge was extended without revising static calculations, and the self-weight of the structure exceeded its resistance, resulting in structural failure [14].

Although bridge design and construction concepts have attained high standards ever since the Quebec bridge collapse, structural failures still occur worldwide, despite implementation of modern technologies and innovations in the civil engineering practice. More than a century after the Quebec bridge, in 2018, a pedestrian overpass situated in Miami, USA, collapsed during construction. As the bridge was being built over the highway without interfering with the traffic underneath, the collapse resulted in six fatalities, all of them in the vehicles passing under the bridge. Based on [15], the investigation proved that the bridge failure was due to design flaws. The Quebec and Miami bridge failures, although more than a century apart, do have something in common. The investigations proved that structural deficiencies were noticed on both bridges in the days leading to collapse. In Quebec, the exceeded buckling and deflections of the superstructure were visible [14] while in Miami, the cracks 


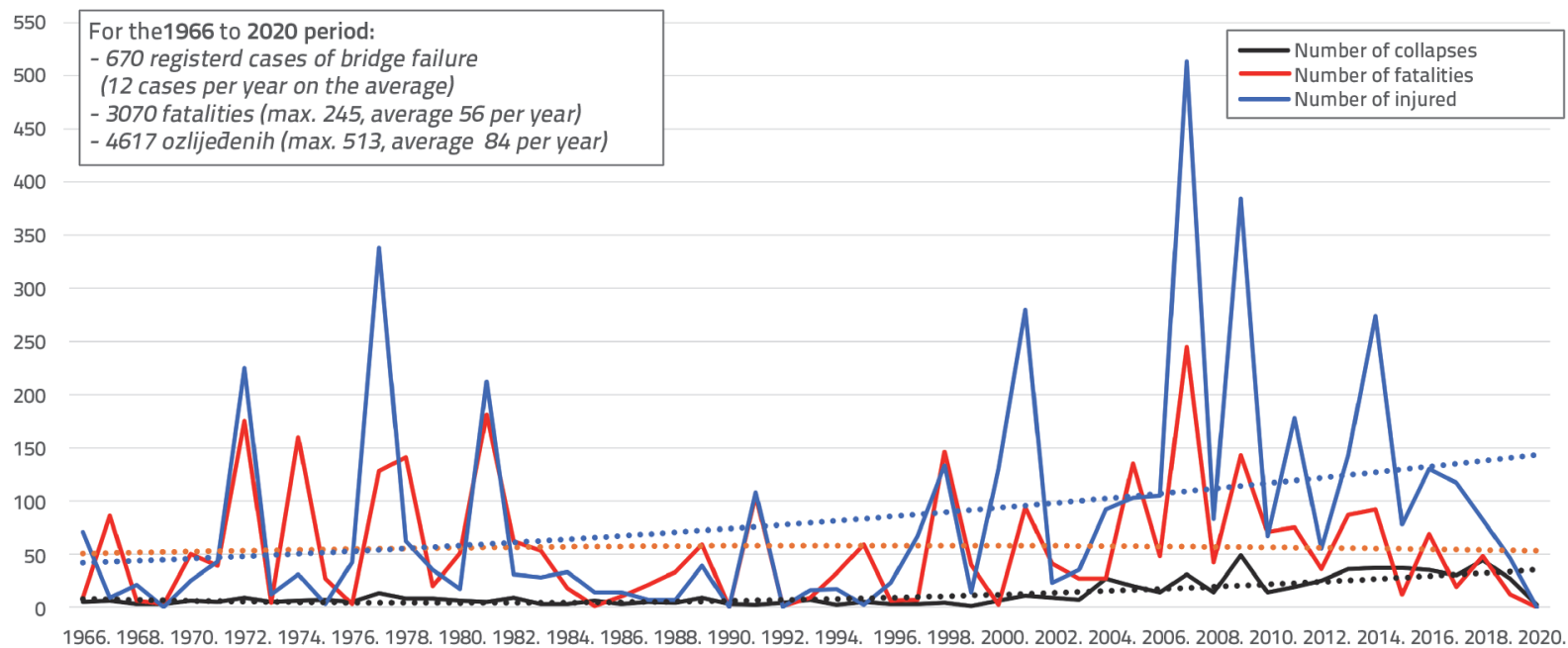

Figure 3. Statistical analysis of IABSE bridge failure database presented in terms of annual bridge failures and their consequences for human lives and health (based on the [18])

propagation [15] should have signalled the engineers to stop the construction and investigate the reasons for such deficiencies before the catastrophic event.

Another recent bridge failure that shocked the world is the Morandi Bridge collapse in Genoa. The bridge was built and opened to traffic in 1967. It was strengthened and reconstructed in the 1990s, when the SHM (Structural Health Monitoring) system was installed, which enabled continuous monitoring of bridge performance. Despite this, during the thunderstorm that occurred in August 2018 , one of the spans suddenly collapsed, resulting in over 40 fatalities [16]. The official cause for the Morandi bridge failure has not as yet been (publicly) determined, but the preliminary and unofficial reports suggest that the combination of design flaws, questionable construction procedures, and negligence in bridge maintenance, culminated in bridge collapse. On the other hand, it has been shown that structural failure could also be triggered by extreme weather conditions which occurred at the time of the collapse [17].

Proper documentation and analysis of all types of structural failure, such as those listed above, are highly significant because the conclusions and lessons learned can be used by engineers in order to reduce the number of failures in the future. The reasons for failures can lie in the design, construction or maintenance and operation phases of the bridge service life. Statistical analysis of documented failures focusing on bridge type (e.g., typical critical sections and situations) can help in identification of main causes leading to bridge collapse. Based on these findings and appropriate training of operators, bridge owners and maintenance engineers would be able to react promptly, and prevent catastrophic events like the one in Miami [15].

The analytical processing, categorization and statistical analyses of data presented in this paper are based on 670 examples of bridge failure worldwide, which occurred between 1966 and 2020. These examples were collected in the scope of the IABSE task group TG1.5. "Performance Based Design Founded on Lessons from Bridge Failures" and were given to the authors for post-processing.
The available database provides list of bridges, their location, type, year and service life stage in which the failure occurred, casualties' data, and main causes of failure with the corresponding human factor. These factors provide the basis for the systematization and statistical analysis of main causes of bridge failure along with the corresponding human factor. Each of the main causes is divided in subcategories that are described and backed by real-life examples (if the data is available), and the analysis is made to determine the most common cause of bridge failure in each category (sections 3.2. to 3.6.). The same principle is used for the analysis of human factor, as given in Section 3.7, while the summary is presented in Section 3.8. Figure 4 presents the moment in bridge service life in which the collapse occurred (during construction, during reconstruction, during demolition, during operation: opened to traffic or closed to traffic). The data on the total number of fatalities (3070) and injured (4617) individuals are also available (Figure 3) [18].

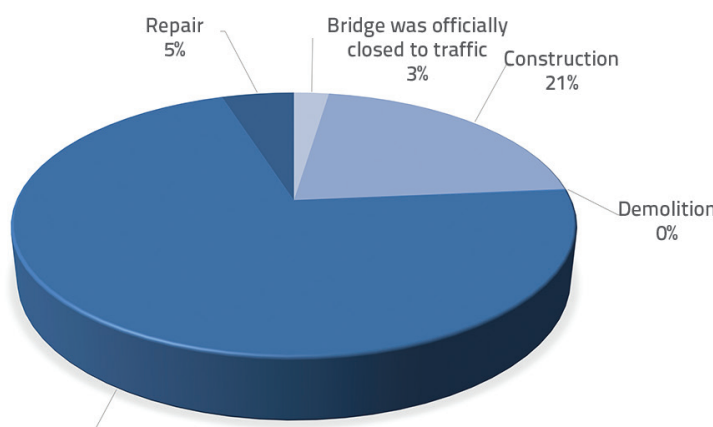

Operation without

interruption of traffic

$71 \%$

Figure 4. Bridge service life stages at the time of collapse

The country-based analysis of bridge failures is not presented to avoid biased results, as the available database does not cover all bridge failures that occurred worldwide in the given period. This decision is validated with more recent research from India [19] and China [20], which is not included in IABSE database as the data is not 
available to public. For example, [19] shows that over 2000 complete or partial bridge failures occurred during last four decades in India alone, while the paper [20] describing the failure of Zijin Bridge states that in China 418 partial or complete bridge failures occurred in the period between 2009 and 2019.

In the authors' opinion, the inclusion of all available data on bridge failures in the existing database, along with its subsequent analysis, would be a first step toward establishing the cause-and-effect connection between the country-based design codes and the reliability of its bridges. Unfortunately, such research is not possible at the moment as the bridge failure records are not publicly available in a number of countries, and it would also be beyond the scope of this paper.

The main causes of bridge failure can be classified into five main groups:

- Insufficient expertise in the design and/or construction

- Excessive live load (overloading)

- Extreme events (floods, fires, earthquake etc.)

- Deterioration of built-in material (e.g., reinforced concrete)

- Extreme traffic events (ship colliding with bridge elements, vehicle collision under the bridge, etc.)

These causes are described in more detail in sections 3.2 to 3.6., and their representation in the available database is presented graphically in Figure 5.

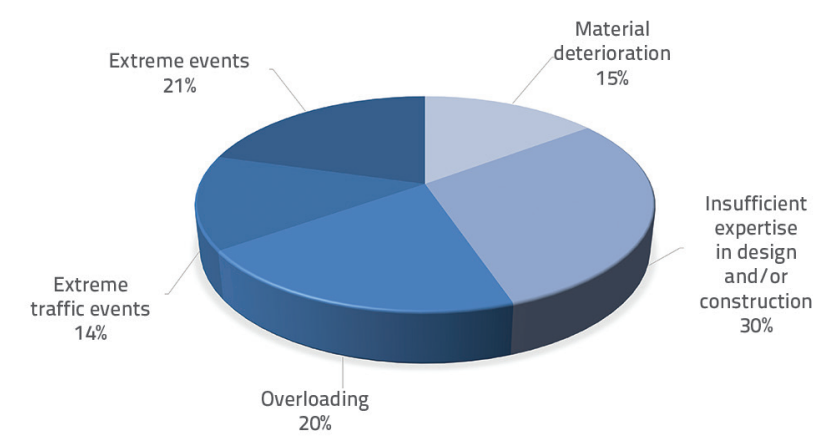

Figure 5. Main causes for the bridge collapse

\subsection{Insufficient expertise in design and/or construction}

Insufficient expertise implies errors at the design and/ or construction stages, negligence during construction, and insufficient knowledge of the engineer in charge. The representation of these subcategories is given in Figure 6. At the design stage, errors could occur during static and dynamic calculations and verifications or in the detailing phase when, for instance, reinforcement drawings are produced. Errors can occur due to insufficient knowledge of current design codes and so, for instance, traffic load effects are sometimes not properly accounted for on critical bridge sections. At the construction stage, errors can occur due to negligence and lack of accountability during construction, but also due to unknown risks or defects in the built-in materials. In the past, bridge collapses with the highest number of fatalities occurred at the construction stage as a large number of workers was usually present at the construction site [21]. In addition, in former times, bridge design would typically consist of stress diagrams only, while the contractor and supervising engineer would be in charge of the detailing and elaboration of the final design [22]. Nowadays, design documents for complex structures (including all medium and long span bridges) are revised [23] by a third-party structural engineer, based on his experience and expertise in the specific field of engineering [24], the aim being to minimize design errors.

On the other hand, the duty of the engineer in charge of construction site supervision is [25]: "To be familiar with the design project, detailing and construction technology used by the contractor in order to notice possible deviations on the construction site". Furthermore, he oversees quality control of built-in materials based on the values defined in the design. Current codes regarding material characteristics, including the related quality control checks, are much more sophisticated when compared to practices applied in the early twentieth century. In general, for the realization of a large construction project, it is critical to ensure proper coordination and communication between all interested parties (structural engineer, contractor, and supervising engineer) so that all potential problems and deviations that might occur at the construction stage can successfully be solved. The on-site supervising engineer should be familiar with the design process while, on the other hand, the structural engineer needs to be regularly updated about developments on the construction site, so that possible defects can be reduced to minimum.

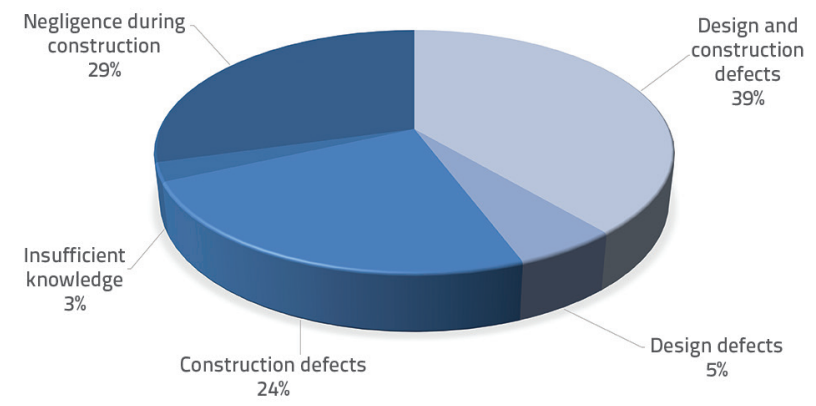

Figure 6. Subcategories of main cause of failure: Insufficient expertise

New technology for optimising the life cycle of structures involves implementation of the BIM (Building Information Modelling) approach. BIM is a multi-dimensional integrated system that includes a project database that is available to all included parties, in order to maximize the efficiency and quality of the project, to reduce risks and deficiencies, and to optimize the project management process [26-28].

\subsection{Extreme events}

During the design process, structural engineer takes into account all environmental actions that are defined in the current 
design standard. Nevertheless, it is impossible to predict extreme events that occur in extremely rare situations. These events, such as earthquakes, floods, thunderstorms, tsunamis, etc. can have devastating effects on structures, often resulting in partial or complete bridge failure. A spike in bridge failures due to extreme events is attributed to bridges being situated at inaccessible locations, but also to more extreme weather conditions [29]. Climate changes are increasing the frequency of extreme events, which presents a challenge to the ageing transport infrastructure worldwide [30]. A representation of extreme events from the analysed database is given in Figure 7, where man-made hazards, such as vandalism and terrorism, are also included. Detailed analysis and prediction of extreme events (natural hazards) are not possible due to insufficient data, as such events occur very rarely. Available records are used for the development of characteristic values, which are multiplied with partial safety factors, as defined in relevant Eurocode [31].

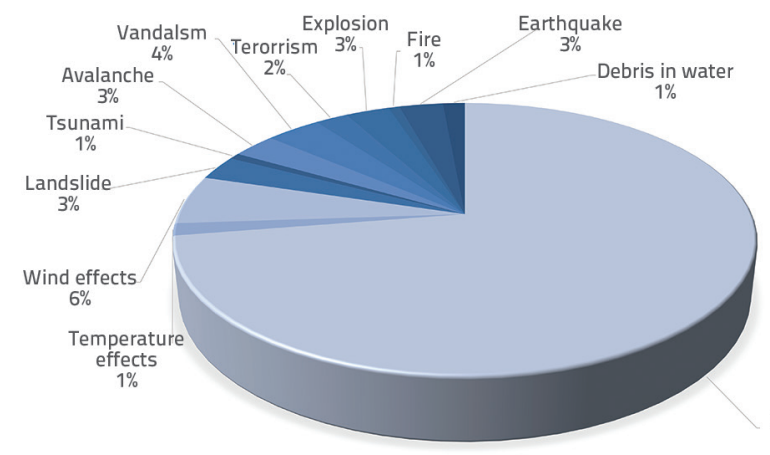

Figure 7. Extreme events as causes of bridge collapse

It is impossible to obtain an absolute structural reliability. Thus, bridges are usually designed for the service life of 50 or 100 years, depending on bridge type and characteristics. The collapse of the Tacoma Narrows bridge in the USA in 1940 is probably one of the most famous and best-documented bridge failures due to extreme events (wind). A number of papers [32-34] have been published on the subject and the research interest does not wane. In general, aerodynamic and static forces induced by extreme wind effects present an engineering challenge in the design process for longer span bridges [21], and the codified values are not always applicable. For example, it is stated in [35] that the 10-minute reference wind speeds from current design codes [36] are not applicable to long-span bridges situated in the Croatian coastal region, as they do not take into account the effects of turbulence.
Earthquakes of higher magnitudes, being extreme events that severely affect all types of structures, are extremely rare, which results in discussions on precautionary measures to be applied in the design process [37]. However, when they occur, earthquakes can have catastrophic consequences in terms of both property loss and casualties. The awareness of the engineering community about earthquakes has improved drastically during the $20^{\text {th }}$ century, when appropriate design codes were also introduced. During the earthquake, soil shifts in both horizontal and vertical directions, which can result in scouring under the bridge substructure, and eventually lead to failure [21]. The probability of structural damage increases with bridge age and depends on characteristics of the subsoil [38]. The earthquake structural engineering is constantly improving, based on the experience and structural response recorded after each significant earthquake [39]. An example of abutment damage due to scouring after the 2020 Petrinja earthquake in Croatia is presented in Figure 8. It is a bridge over the Maja River, situated at the southwest entrance to Majske Poljane. The bridge had been poorly maintained for years before the earthquake, and the earthquake additionally separated stone blocks at the abutment. The bridge was immediately closed to traffic but, as it is located on an important route, where traffic greatly increased after the earthquake, the intervention on the abutment had to be made without delay. Temporary retrofitting with stone blocks was conducted to protect the abutments from scour, and also to provide additional horizontal soil pressure to stabilize the abutment wall and wingwalls. After completion of these activities, the bridge was re-opened to traffic. This example, and situation is similar at other older bridges, unfortunately proves that irregular and inappropriate maintenance results in structural deterioration that significantly increases the risk of structural failure when combined with extreme events.
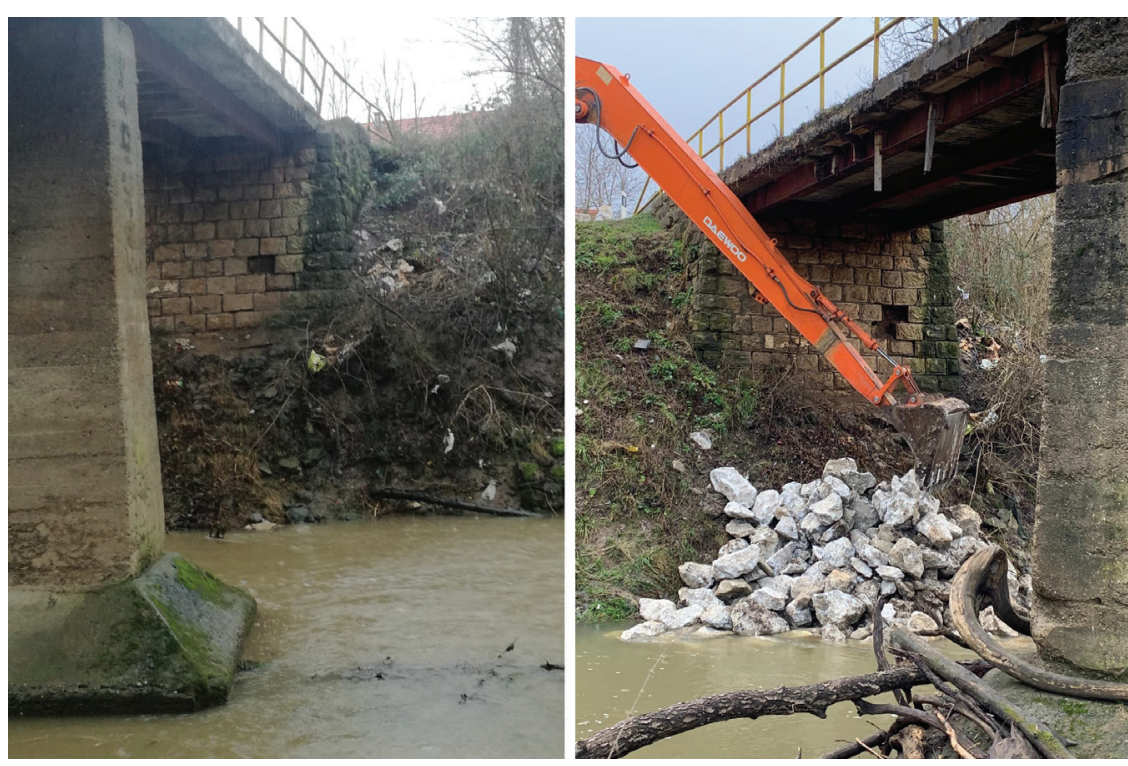

Figure 8. Damage to bridge substructure after earthquake in Petrinja (left) and temporary retrofitting in order to open the bridge to traffic (right) 
Scouring can also be caused by flood events [40] which are becoming more frequent as a result of climate change. In fact, floods are the main cause of structural failure by extreme events (Figure 7). In particular, flooding causes damage to bridge substructure, resulting in displacement of abutments and piers and, if the water level is high enough, it can damage or remove bridge bearings. In such cases, the superstructure of the bridge is indirectly damaged due to displacements, which can result in structural failure. Displacements of substructure caused by scouring could also result in structural failure when the bridge is subjected to usual traffic load, or to a non-critical earthquake load [41]. Floods can also directly damage the bridge superstructure if it is submerged during a flood event, which results in damage depending on the time during which the superstructure was under water. The Sava-Jakuševac railway bridge in Croatia is an example of a partial bridge failure due to scouring and erosion of subsoil. In 2009, it was closed to traffic when high level of the river under the bridge caused scouring and large displacement of one of the piers, which resulted in extreme deflections of the steel superstructure [42].

Bridge collapses caused by fire were quite frequent in the past when bridges were made of wood, but nowadays they are very rare. Steel bridges are subjected to fire damage as elevated temperatures cause a reduction in stiffness and extreme displacements [43], but only if the material reaches a critical temperature of $723^{\circ} \mathrm{C}$. An example of a steel bridge damaged by fire is given in [44]. Quick reaction of fire department prevented failure of this steel bridge. Reinforced and prestressed concrete bridges (and structures in general) are more resistant to fire, due to thermal properties of concrete and protection it offers to the reinforcing steel [45].

In addition to extreme events caused by natural hazards, bridges are also vulnerable to man-generated hazards, including terrorism, explosions, vandalism, and wars. These extreme events are generally not covered by design codes, although HRN EN 1991-1-7 [46] provides guidelines for structural design as related to explosions.

\subsection{Overloading}

According to the current design code for traffic loads imposed on bridges, new bridges should be able to withstand characteristic traffic load values for the reference period of 1000 years $(5 \%$ probability of exceedance in 50 years). However, the majority of bridges in the EU and USA have been built more than fifty years ago, and were designed according to older codes [47], which were not as conservative as the new ones [48].

Bridge failures due to overloading are in general caused by live (traffic) load (over $99 \%$ ) but can also be triggered, albeit very rarely, by self-weight, as presented in Figure 9.

Rapid traffic growth (both in volume and weight) has been registered over the last 50 years and is due to fast urbanization and an increasing demand for transport of both goods and people [49]. According to [50], the percentage of urban areas increased from $30 \%$ to $50 \%$ during the $1950-2018$ period. Furthermore, it is predicted in [51] that the number of vehicles will increase from one billion in 2010 to two billion in 2030. At the same time, to reduce the total number of vehicles, governments are discussing an increase in the maximum allowed vehicle weight [52], which would affect older bridges that are already in critical condition.

It is obvious that older existing bridges are at the limit of the initial load bearing capacity for which they were designed according to old codes and traffic models. Considering these changes in circumstances on the roads and highways worldwide, some older bridges will inevitably collapse due to overloading.

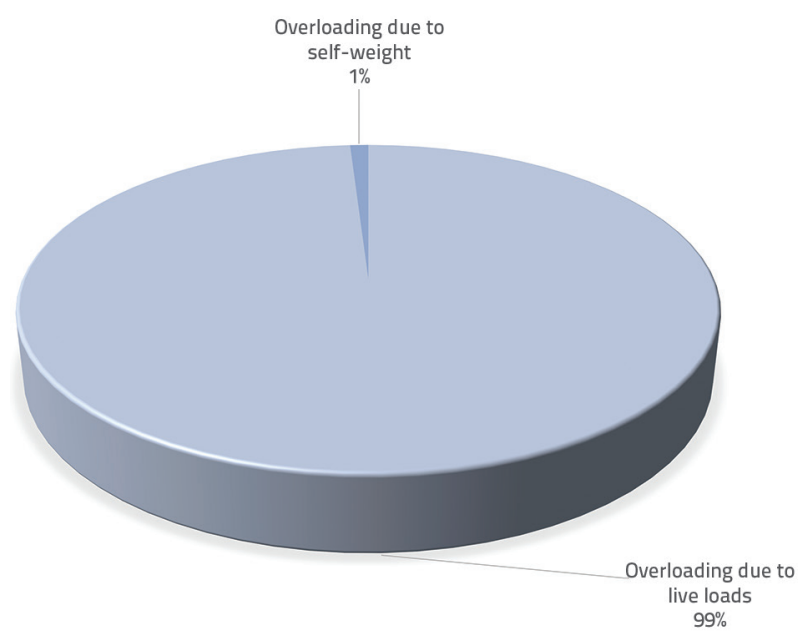

Figure 9. Bridge failures caused by overloading

According to [40], there are two main reasons for bridge failure due to overloading. The increased weight and the higher frequency of use of heavy vehicles, which exceeds the traffic load models used in the design and construction, resulting in immediate failure. Furthermore, the increased use of heavy vehicles rapidly increases the extent of damage caused by fatigue, most notably on steel and composite bridges [40,53]. Therefore, the modelling of traffic load effects for the existing bridges should be conducted using more advanced analysis methods, compared to those used for new bridges [49].

\subsection{Structural deterioration}

Structures in general, including bridges, are not eternal but are designed and built for a certain period of time, defined as service life. Furthermore, in order to last for a defined period of time, structures require regular maintenance and operation. Building materials used for the construction of bridges are subjected to various environmental and external effects, resulting in their deterioration. Current design standard defines structural reliability (which includes safety, serviceability and durability) of new structures as the level of reliability at which deteriorations during the design service life will not affect structural integrity 
more than expected, taking into account environmental effects and regular maintenance $[31,54]$. Material deterioration that can result in bridge collapse includes corrosion, fatigue, deterioration of reinforced concrete, deterioration of bricks, concrete shrinkage, and creep, rotting of wood, fragility, and freezing and thawing cycles. Individual effects that can lead to bridge collapse are presented in Figure 10.

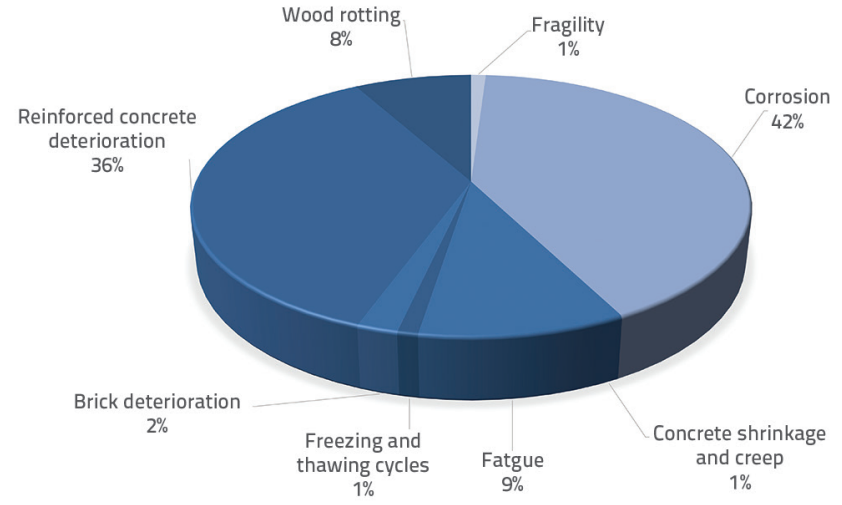

Figure 10. Bridge failures caused by material deterioration

Material deterioration is caused by environmental effects and climate changes, such as temperature variations, increase in rainfall and relative humidity, higher concentrations of carbon
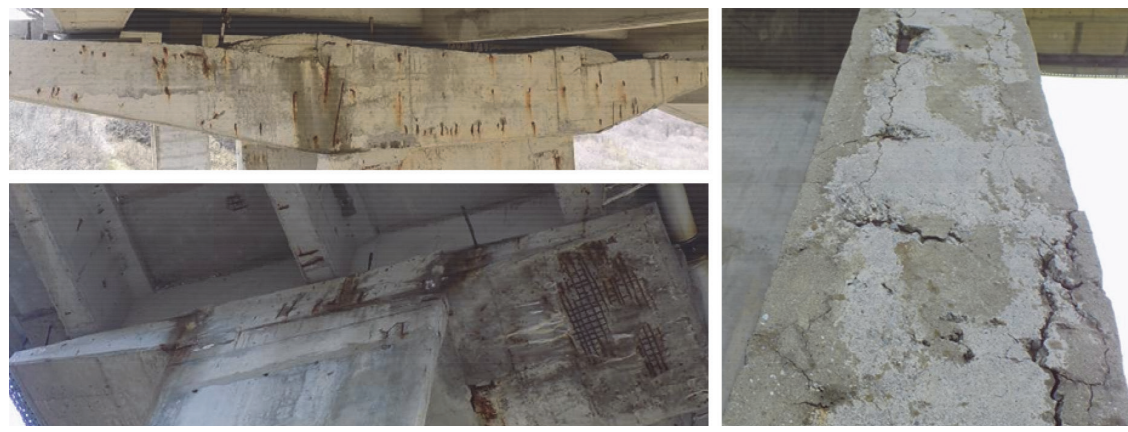

Figure 11. Deterioration of reinforced concrete due to corrosion at Bukovo Viaduct in Croatia
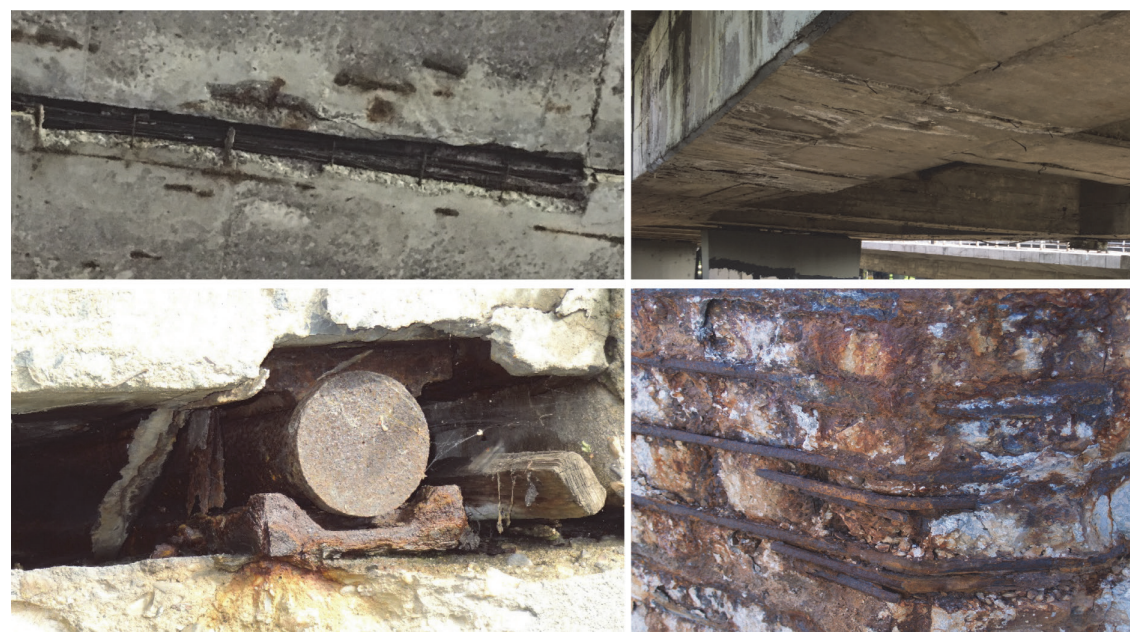

Figure 12. Deterioration of reinforced concrete due to corrosion at bridges in Zagreb, Croatia dioxide [55], etc. It is therefore important to take into account environmental effects at the design stage, as natural processes such as corrosion of steel, rotting of wood, etc. reduce service life of materials and of the structure itself [56]. Corrosion of both structural and reinforcing steel is one of the main causes of structural deficiency of structures in general, and bridges in particular [57-59].

Examples of reinforced concrete deterioration due to corrosion of reinforcing steel are presented in figures 11 and 12. Figure 11 shows the level of deterioration of the Bukovo Viaduct built in the early 1980s, which is currently undergoing a major reconstruction. Bridges in the city of Zagreb have also been affected by deterioration (Figure 12), and have been reconstructed over the last couple of years, but the current extent of deterioration would not have been reached if they had been properly maintained in the past.

Real-life examples prove that insufficient maintenance of bridges lead to severe deterioration, which is an issue that is faced by many existing bridges worldwide. Some bridge collapses could have been avoided if regular maintenance, inspection, and assessment procedures had been conducted. Furthermore, investigations proved that some previous bridge collapses caused by various reasons could have been avoided if the inspection and assessment had been conducted more thoroughly. After the bridge is built and opened to traffic, its operator has the responsibility to maintain a defined level of maintenance and inspection in order for the bridge to reach (and even operate beyond) its design service life. If inspections show that some parts have deteriorated to the level at which they are likely to affect bridge reliability, they should be replaced, and if traffic conditions on the bridge change during its service life, the reassessment and possibly strengthening should be conducted.

\subsection{Extreme traffic events}

Extreme traffic events that can result in bridge collapse are all types of traffic accidents on and under the bridge, including vehicle collisions on the bridge, vehiclecollisions with bridge substructure under the bridge, ship collisions with substructure or superstructure, etc. These accidents occur due to non respect of overhead clearance, collision with bridge superstructure caused by excessive height of vehicles or cargo, derailment of trains at the bridge or before the bridge, and rail displacement. Accidents also occur due the skidding of 
vehicle on bridges because of ice on the roadway or inadequate driving speed, resulting in collision with parts of the bridge or other vehicles. Furthermore, for bridges spanning rivers and waterways, these accidents occur when a ship collides with bridge pier, abutment, arch, or superstructure. Although ships pass under the bridge at a relatively low speed compared to trains and road vehicles, they can cause significant damage due to their weight, which can even result in bridge collapse [40]. Classification of extreme traffic events as main causes of bridge collapse is presented in Figure 13. An increase is in these cases attributed to traffic volume and weight increase registered over the last decades, which has resulted in a number of cases of ships colliding with bridge piers [29]. Current design codes [46] provide guidelines for extreme events design, including vehicle, train and ship collisions with bridge elements. Characteristic values are defined based on the consequences of collision, approximate volume, weight, and type of traffic, and all precautionary measures taken (elastic fence on the bridge, barriers in the waterway around piers, etc.). Design code HRN EN 1991-2 [48] defines the design of an extreme event as: "Loads due to road vehicles should be taken into account with regard to extreme design situations, involving vehicle collision with bridge piers or decks, vehicle collision with kerbs, parapets and structural components, and presence of heavy wheels or vehicles on footways."

Based on previous experience and lessons learned, certain precautionary measures are now taken into account in the design of new bridges, such as implementation of design solutions without central columns/piers on roadways and, when columns/piers can not be avoided, they should be much more robust. ON railways, the gaps between the rails and piers has been increased, and piers are designed for a much greater impact load. On the existing bridges, piers can be strengthened with FRP or steel sheeting so that they can withstand greater collision force.

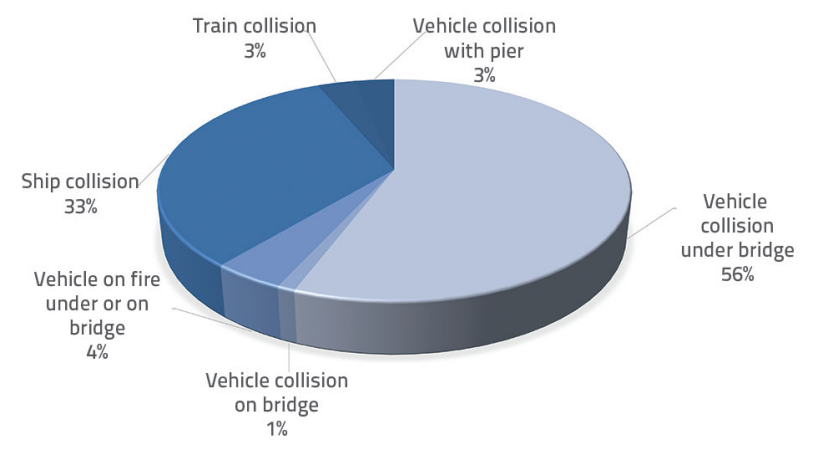

Figure 13. Bridge failures caused by extreme traffic events

\subsection{Human factors in bridge failures}

Although forensic investigation of bridge failure events shows that technical aspects are of crucial significance for avoiding premature collapse of bridges, human factors are also in many cases responsible for the collapse. Forensic engineer Neal
FitzSimons described the human factors as [60]: "four horsemen of the engineering apocalypse: ignorance, incompetence, negligence and greed".

Human errors can be either accidental or intentional. Managing human factors in all stages of bridge design, construction and operation is a key element for ensuring long service life of bridges. Even though the codes and guidelines are continuously improving, human errors are still present, and their consequences can be catastrophic. During the structural reliability assessment, the focus should be on human factor, as a complex and unpredictable parameter. At that, it should be emphasized that the reliability of structures does not depend on a single decision only, as it can be influenced by a number of uncertainties. The main reason for collapse is given in the bridge failure database analysed in this paper. However, human factor is also provided as an additional reason for collapse, i.e. it is indicated what action should have been taken to prevent the collapse/failure. Thus, human factors have been taken into account in this analysis, as shown in Figure 14.

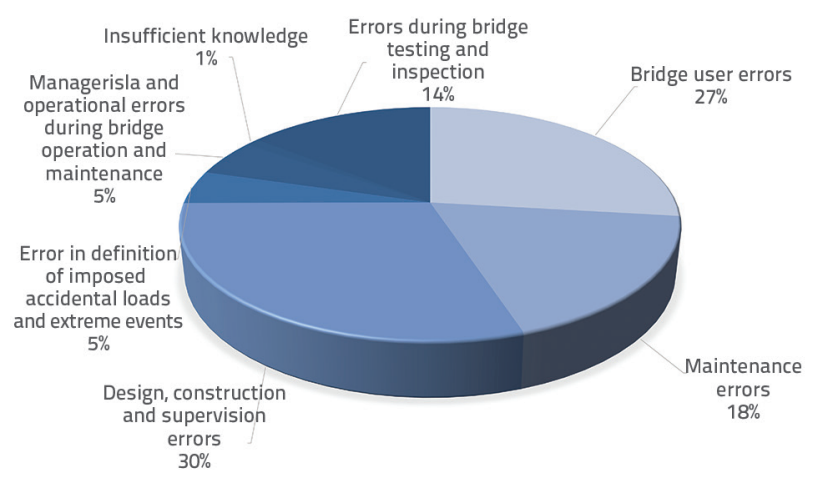

Figure 14. Human factors as additional causes of bridge failure

\subsection{Discussion}

It can generally be stated that bridge collapse events are not caused by a single isolated factor. The reason that finally triggers the collapse is in most cases preceded by causal sequence of events leading to structural failure. Main reasons for collapse can be classified into five main categories as follows: design and construction defects $(30 \%)$; extreme events $(21 \%)$; overloading $(20 \%)$, material deterioration (15\%), and extreme traffic events (14\%) (Figure 5).

The most common individual reasons are presented in Figure 15 , as design and/or construction defects (design defects; construction defects; design and construction defects) (20\%); overloading due to live load (20\%); flood (15\%); negligence during construction ( $9 \%$ ); vehicle collision under bridge (8\%); corrosion (6\%); reinforced concrete deterioration (5\%); and ship collision (5\%). These causes are responsible for $88 \%$ of bridge failures from the analysed data.

Figure 14 shows that human factors are an important parameter in bridge failure events. The most common human factors are 


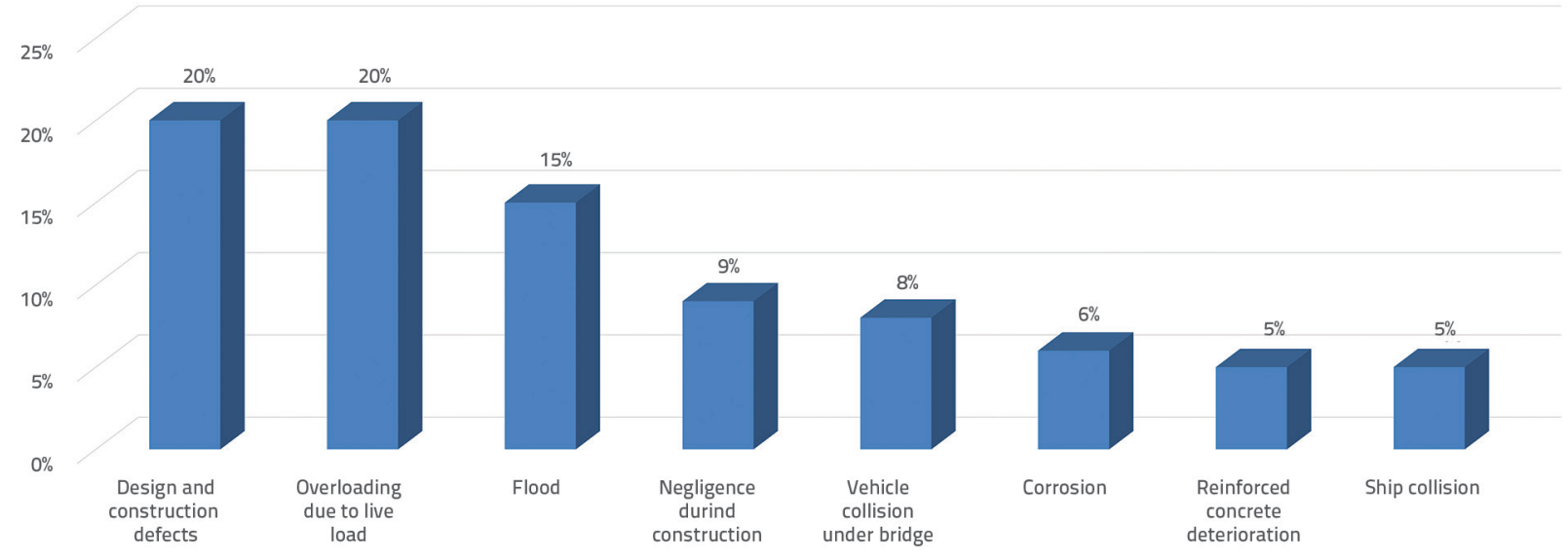

Figure 15. Most common individual causes of bridge collapse

errors in the design, construction, and supervision activities. It is interesting to analyse the human factor at the stages of bridge construction and operation (Figures 16 and 17). During the bridge construction process, errors made by engineers in charge account for the majority of bridge collapses with $96 \%$ (Figure 16), while during the bridge operation and service life, the most common human factors involve bridge users with $36 \%$ (Figure 17).

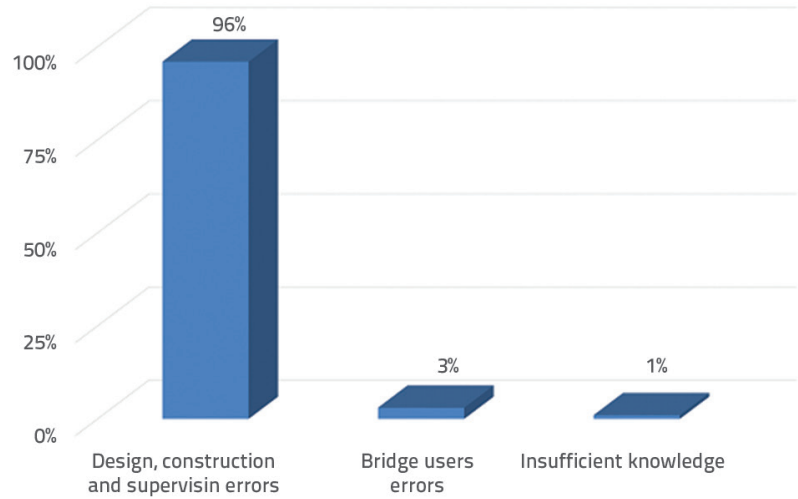

Figure 16. Human factors causing bridge collapse at construction stage
The number of bridge failures would be decreased significantly through implementation of a more efficient bridge management system (BMS), development of clear and detailed guidelines on the type and frequency of bridge inspections, and by providing for engagement of competent and duly qualified engineers. Proper identification of deteriorated structural elements and significant damage is necessary throughout the service life of the bridge. Past experience and analysis of database in this paper clearly shows that inadequate operation and maintenance of bridges could result in a significant increase in final cost in the case the failure/collapse actually occurs, as presented in [47].

\section{Guidelines for avoiding progressive collapse and achieving robust structures}

\subsection{Introduction}

Design of new structures, as defined in current codes [31], is based on reliability engineering and implementation of a semi-probabilistic approach where uncertainties are taken into account with partial safety factors for both load effect and structural resistance. On the other hand, these codes are overly conservative for the assessment of existing structures, bridges

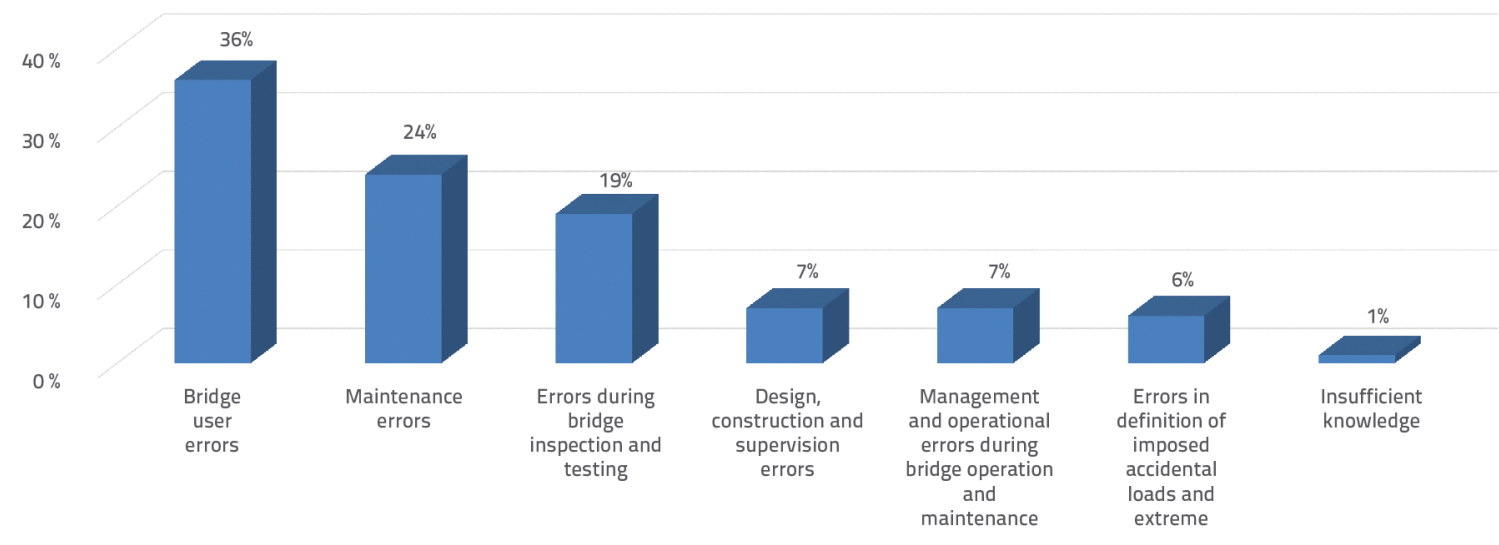

Figure 17. Human factors causing bridge collapse at operation stage 
in particular, and significantly better results are obtained when the full probabilistic approach is used, as presented in $[47,49,61]$. In the design process for new structures, it is important to take into account, based on the level of importance of a particular structure, all possible failure mechanisms and external load effects that can occur during the designed service life of the structure. In this way, attempts are made in the design process to avoid structural damage that is disproportionate to the actual cause of the damage, and that could lead to full collapse of the structure [62]. Such an event is described as "progressive collapse" in which local structural damage results in gradual failure of the entire structure $[63,64]$. In order to prevent progressive collapse, the structure and its structural elements must be able to absorb the damage inflicted on individual elements during and after an extreme event. The remaining capacity of the structure is most frequently referred to as its resistance (bearing capacity), but may also refer to its deformability, ductility, stability, weight, mass and stiffness, as any of these properties can in a particular case prove critical [65]. This property of the structure is defined by a single term as its robustness, and it comprises a number of parameters that need to be taken into account during the design or strengthening of a structure [62]. A short overview of structural robustness and progressive collapse and their causality is given in this section.

\subsection{Progressive collapse}

The concept of progressive collapse has been used by structural engineers ever since the collapse of the Ronan Point apartment building in London. Only two months after it was completed in 1968, the gas explosion on the $18^{\text {th }}$ floor blew out the outer load-bearing walls and caused the collapse of the entire corner of the building on all 22 floors, resulting in 17 fatalities and more wounded. The consequences were deemed unacceptable for such damage, terming the phrase and concept of progressive collapse [62]. Another significant structural failure related to progressive collapse is the failure of the World Trade Center (WTC) towers in New York after the devastating terrorist attack in 2001. After the WTC collapse, the research on robustness and progressive collapse has gained greater momentum, and has been based on highly advanced computer-aided methods.

The basic concept of progressive collapse is that the local structural damage initiates a chain reaction which results in partial or complete structural failure, making the consequences unacceptably severe when compared to initial damage [6668]. If there is a disproportion between initial damage and the resulting structural failure, it is described as disproportionate collapse. However, progressive collapse can lead to disproportionate collapse, but the disproportionate collapse is not necessarily a progressive one. Nevertheless, it is common that the disproportionate collapse occurs progressively [69]. Starrosek [70] defined six basic types of progressive collapse: pancake-type; zipper type; domino type; section type; instability type, and mixed type. Pancake type occurred during the collapse of WTC towers and is characterized by the initial failure of a vertical load-bearing element (column, wall), which results in the fall of structural components in vertical direction, and in failure of other vertical loading elements beneath due to impact load.

The zipper type collapse occurs when one of the load-bearing elements fails and the subsequent load is transferred to the adjacent load-bearing element which cannot absorb the additional load, causing the chain reaction resulting in structural collapse. This type is typical for cable-stayed bridges when the failure of one cable result in complete collapse. An example of zipper type collapse is presented in Figure 18.

- The domino collapse is initiated by the overturning of one element, which collides with the adjacent element and starts the chain reaction similar to that of domino blocks.

- The section type of progressive collapse occurs when a part of the element cross-section cracks due to bending moment (beam) or axial force (column) and the remaining part of the cross-section is unable to absorb additional stress, resulting in cross-sectional failure.

- The instability type collapse is triggered when a part of stabilization (e.g., wind braces) fails, resulting in creation of an instability mechanism leading to structural failure.

- The mixed type is the progressive collapse in which a combination of five main types occurs simultaneously.

Main characteristics of the zipper and section types are the re-distribution of additional loads to remaining load-bearing elements which are unable to absorb it, while in the case of domino or pancake collapses, the transformation of the potential energy to kinetic energy of the damaged element results in complete or partial failure. Some famous bridge failures due to progressive collapses are the Tacoma Narrows Bridge (zipper type) [71] and the Hongqi beam bridge (domino type) $[72,73]$. A typical zipper collapse of a cable-stayed bridge is presented in Figure 18, while the domino collapse of a beam bridge is shown in Figure 19.

An innovative qualitative or quantitative method enabling structural engineers in charge of bridge design or assessment to notice the defects that could result in progressive collapse, is called the fault tree. The development of the fault tree flowchart starts with bridge failure and is elaborated further by identifying the bridge elements which, if damaged, could lead to progressive collapse. Furthermore, each of these elements is further segmented into events that could result in its partial or complete failure [74]. An example of the fault tree flowchart for substructure of a reinforced concrete beam bridge during its operation is presented in Figure 20.

\subsection{Structural robustness}

Robustness as a concept and structural property emerged at the same time as the progressive collapse and has been described and defined since then by a number of authors 
$[62,64]$. However, as there is no empirical or mathematical method to define robustness as a physical parameter, there is no unified definition. Therefore, none of the available national

1

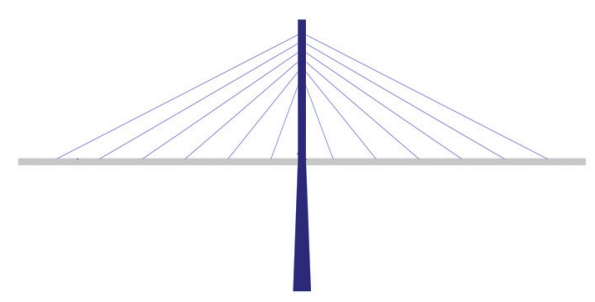

3

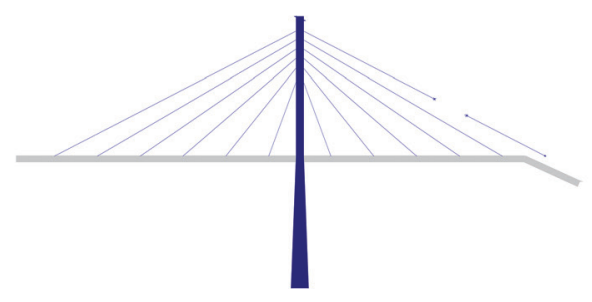

5

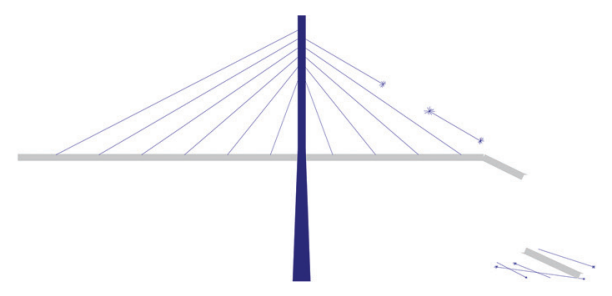

7

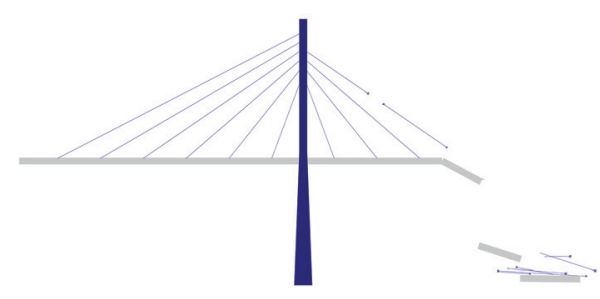

9

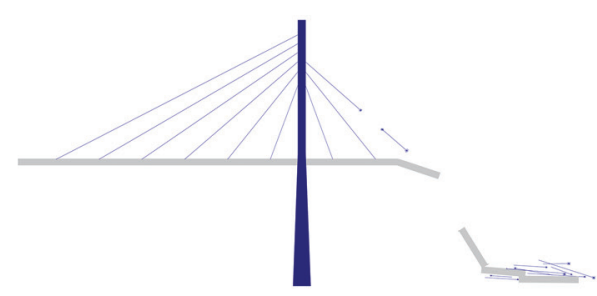

design codes provides a method to calculate robustness, i.e. only guidelines and measures to be implemented in the design process are provided.

2

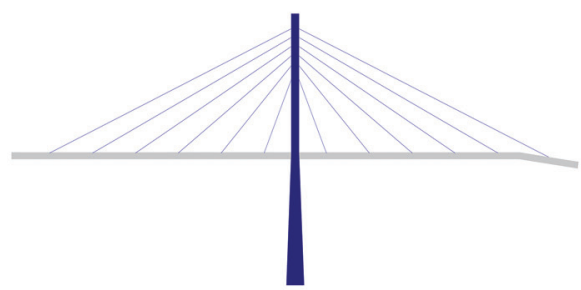

4

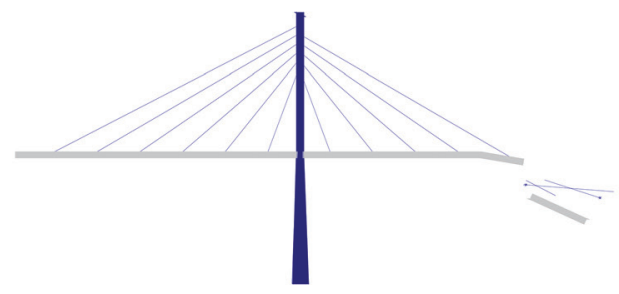

6

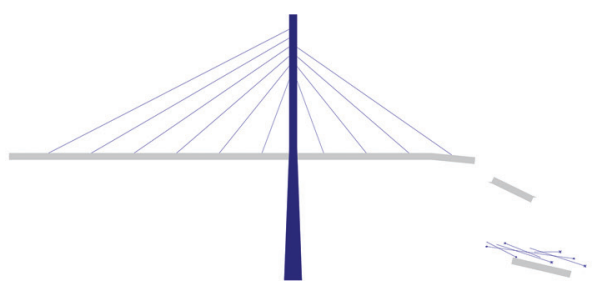

8

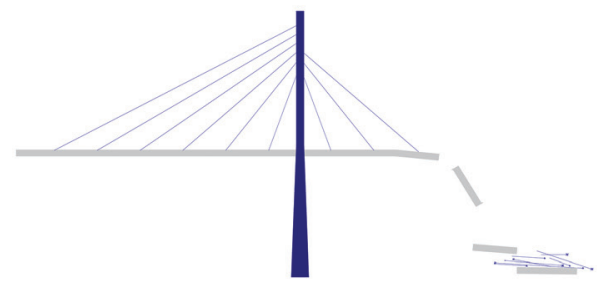

10

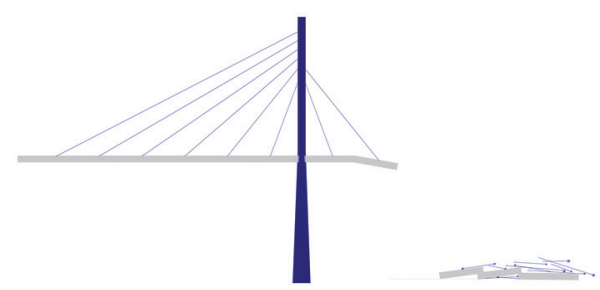

Figure 18. Zipper type progressive collapse of cable-stayed bridge 
1

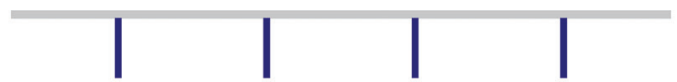

3

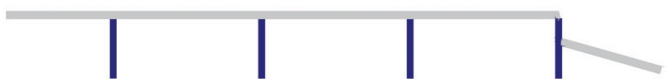

5

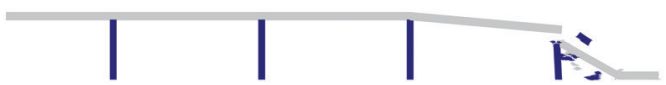

7

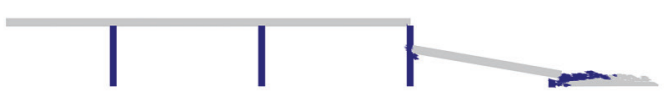

9

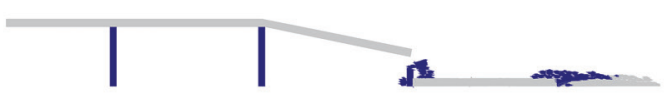

2

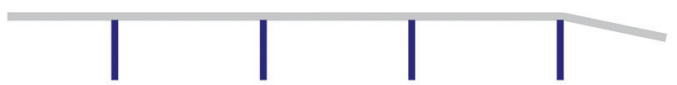

4

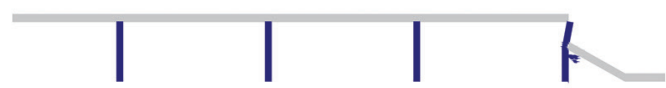

6

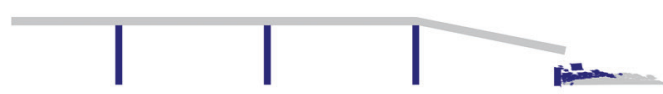

8

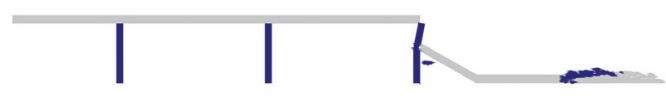

10

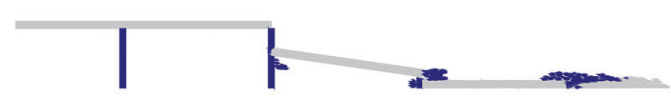

Figure 19. Domino type progressive collapse of beam bridge

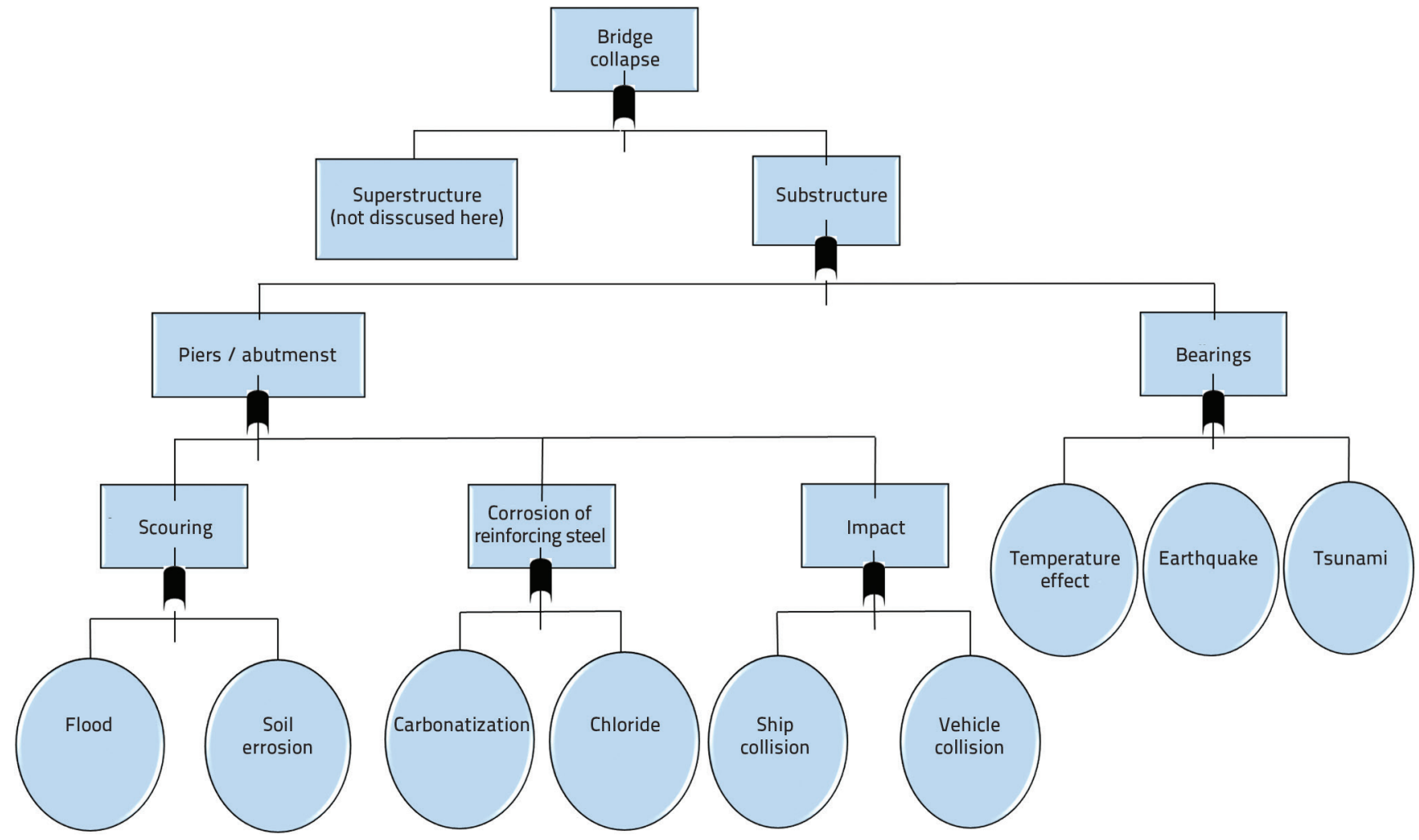

Figure 20. Fault tree diagram

Baker et al. [62] proposed a method for the quantification of robustness. According to this method, a system is considered robust if indirect risks $\left(R_{\text {Ind }}\right)$ do not contribute significantly to the total system risk. They defined the Index of robustness ( $\left.I_{\text {Rob }}\right)$ which measures the fraction of the total system risk resulting from direct consequences $\left(R_{\mathrm{Dir}}\right)$ :

$$
I_{\text {Rob }}=\frac{R_{D i r, 1}}{R_{D i r, 1}+R_{\text {Ind, } 1}}
$$

The values of the index of robustness shown in Equation (1) range from 1 (absolutely robust structures - all consequences of structural damage are direct) to 0 for structures where majority 
of consequences are indirect (disproportionate consequences and extent of damage).

Other authors also proposed mathematical models for the assessment of robustness. These models can be classified as deterministic, probabilistic and models based on risk analysis [75]. Knoll and Vogel [65] define robustness as: "A property of the systems that enables them to survive unforeseen or unusual circumstances". Duncan et al. [76] define it as: "The ability of a system to maintain function even with changes in internal structure or external environment". A majority of current design codes do not define robustness explicitly but request the structures to be designed as robust. For example, HRN EN 1990 [31] states that: "A structure shall be designed and executed in such a way that it will not be damaged by events such as explosion; impact, and consequences of human errors to an extent disproportionate to the original cause." The JCSS Probabilistic Model Code [77] states: "A structure shall not be damaged by events like fire explosions or consequences of human errors, deterioration effects etc. to an extent disproportionate to the severeness of the triggering event." HRN EN 1991-1-7 [46] defines the robustness criterium as: "Designing a building such that neither the whole building nor a significant part of it will collapse if localised failure were sustained, is an acceptable strategy. Adopting this strategy should provide a building with sufficient robustness to survive a reasonable range of undefined accidental actions" and "Measures should be taken to mitigate the risk of accidental actions and these measures should include structural measures in which structural members, and selecting materials, are designed to have sufficient ductility capable of absorbing significant strain energy without rupture. Or preventative measures with which the extreme event is prevented from occurring or its probability and magnitude are reduced." A similar strategy is proposed in [69] with structural measures (additional load-bearing reserves) or nonstructural measures (prevention and reduction of probability that the extreme event will occur). Structural measures are divided into the direct and indirect design for robustness. The direct design aims to explicitly ensure resistance to collapse by verifying whether the structure meets specified performance objectives when subjected to specified hazard scenarios. On the other hand, the indirect design aims to increase the resistance to collapse of a structure implicitly by incorporating consensusapproved design features; this is done without consideration of hazard scenarios and without demonstrating, through structural analyses or other means, that performance objectives have been met [69].

Starossek [78] defines different strategies for the prevention of progressive collapse:

- high safety against local failure (local resistance of critical elements)

- design for load case "Local Failure" (alternative redistribution of loads, isolation by compartmentalization, redundancy)

- design based on current codes. Codes take into account local failures, e.g. stability check of the elements, but in addition to checking all local elements to failure, the system also needs to be checked in the case when a local failure occurs.
Therefore, the system is verified additionally to the load case "Local Failure" (ii) where redistribution of forces is conducted when one of the elements is removed, in which cases global structural system absorbs redistributed loads through mobilization of flexural resistance, axial resistance, or torsional resistance, by activating plastic capacity etc. The Isolation by Compartmentalization (ii) is a design method in which local failure is contained on a part of the structural system by isolating it from the main global load-bearing system. For example, if one of the girders on the bridge collapses, the system remains stable if the others can absorb the redistributed load [78].

It should not be presumed that the structure is robust by itself, i.e. it needs to be designed, constructed and maintained as such, if we wish to reduce possible risks to minimum during the designed service life. For example, dynamic load effects and stresses in a structural element are more critical for brittle material, while a more ductile material can absorb additional kinetic energy and redistributed load [70]. Design approach (i) for increased local resistance of elements demands an increase in element continuity and strength, while isolation by compartmentalization can be achieved with a decrease of continuity and increase in strength [78]. Knoll and Vogel [65] give an overview of robustness elements that can be taken into account in the design of robust structures. Some of them are strength; structural integrity and solidarization; second line of defence; multiple load paths or redundancy; ductility versus brittle failure; sacrificial and protective devices; stiffness considerations; benefits of strain hardening, etc. The strength of structural elements higher than the minimum required in the design codes is often the most feasible strategy to achieve robustness of a structural system. An example of the bridge structural element strengthening can be found on the Pag arch bridge in Croatia, where old slender RC piers were strengthened by applying a new layer of concrete and by encasing the pier in steel sheeting, as presented in Figure 21 [79]. This type of reconstruction is an example of strength increase aimed at gaining greater robustness.

Ductility of material versus brittle failure, presented in Figure 22 , is an important element for achieving other robustness elements (e.g. second line of defence, redundancy) [65]. On the other hand, brittle failure occurs due to material characteristics, local impairments, weak joints, fatigue, or instability due to slenderness.

Redundancy and alternative load distribution paths can be achieved when the structure is designed with multiple loadbearing elements, as in the case of spatial steel trusses. The second line of defence is a preventative method to reduce the probability of extreme events, e.g. elastic railing on and/or under the bridge which will absorb the initial vehicle impact and, if its critical strength is achieved, it will deform by forming a plastic joint, preventing vehicle impact to a structural element of the bridge. In most cases, deformation 

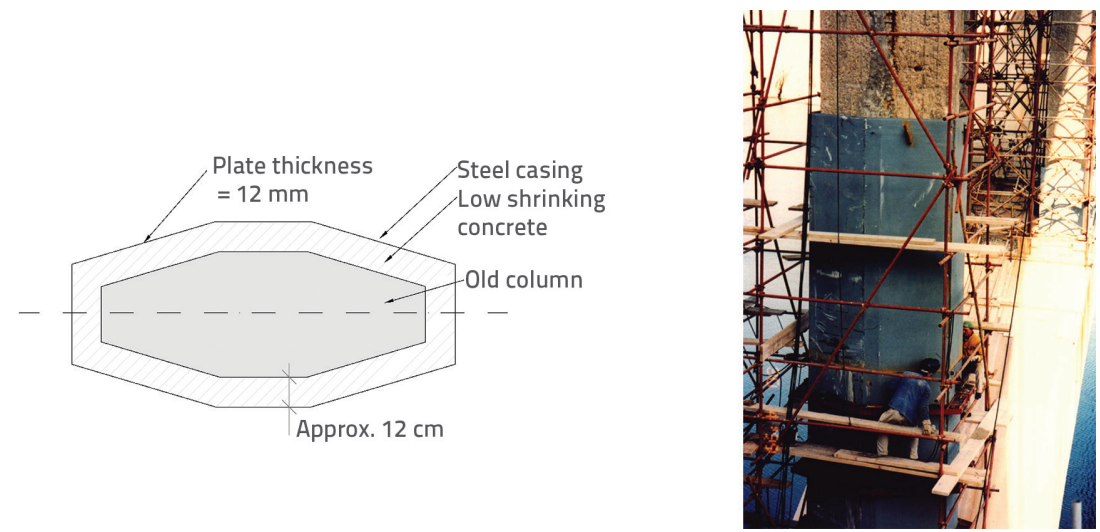

Figure 21. Strengthening of existing RC piers on Pag Arch Bridge in Croatia - cross section (left) and strengthening process (right) - (reproduced from [77]

of material is inversely proportional to stiffness, and one should keep in mind that an increase in ductility of a structure does nor reduce its stiffness. In steel elements, the strength increases with deformation, which is described as strain hardening and is common to lower steel classes. However, it needs to be considered with care for higher steel classes as their compression strength is only by 10 to $15 \%$ greater than the yield stress.

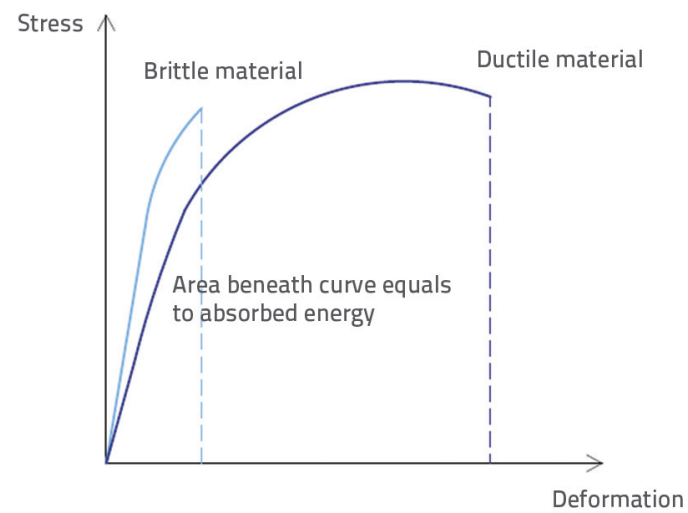

Figure 22. Brittle versus ductile behaviour of material

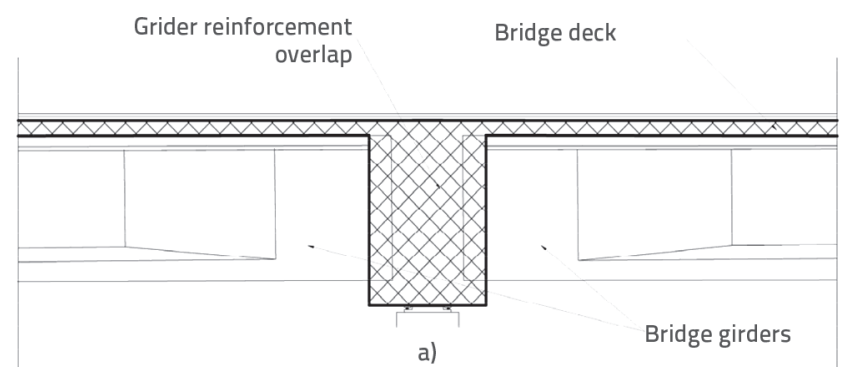

displacement in the case of an earthq retainers are placed, the risk of bridge girder slipping from the bearing block is reduced to minimum, as presented on Figure 24 [80]. Additional approach to achieving robustness in case of an earthquake is by isolating the bridge foundations, as presented in [81].

Sacrificial and protective devices are used as measures for achieving robustness in the case of extreme events. For example, on bridges that are susceptible to ship impact, separate construction elements are placed in front of piers in order to protect them against direct impact. This solution is more feasible when compared to designing bridge piers for withstanding direct impact. Knoll and Vogel also describe some robustness elements to be implemented at the stage of operation of existing structures [65], such as monitoring of structural defects (cracking, delamination, corrosion, excessive vibration, deflection), active interventions, quality control of the construction, operation and maintenance process, and implementation of both passive and active devices (sensors) for constant monitoring.

Some of the above listed elements for achieving robustness, such as full continuity required for alternative load redistribution, are described as questionable in [78], because in some cases

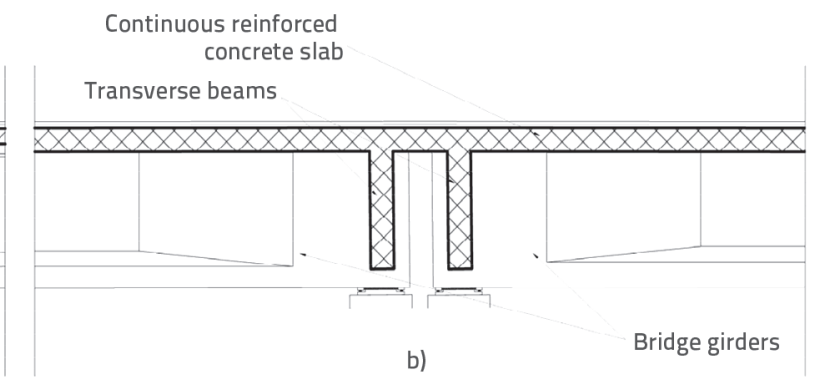

Figure 23. Structural integrity on girder bridges: (a) full continuity (continuous grillage bridge), and (b) partial continuity (simply supported grillage) 

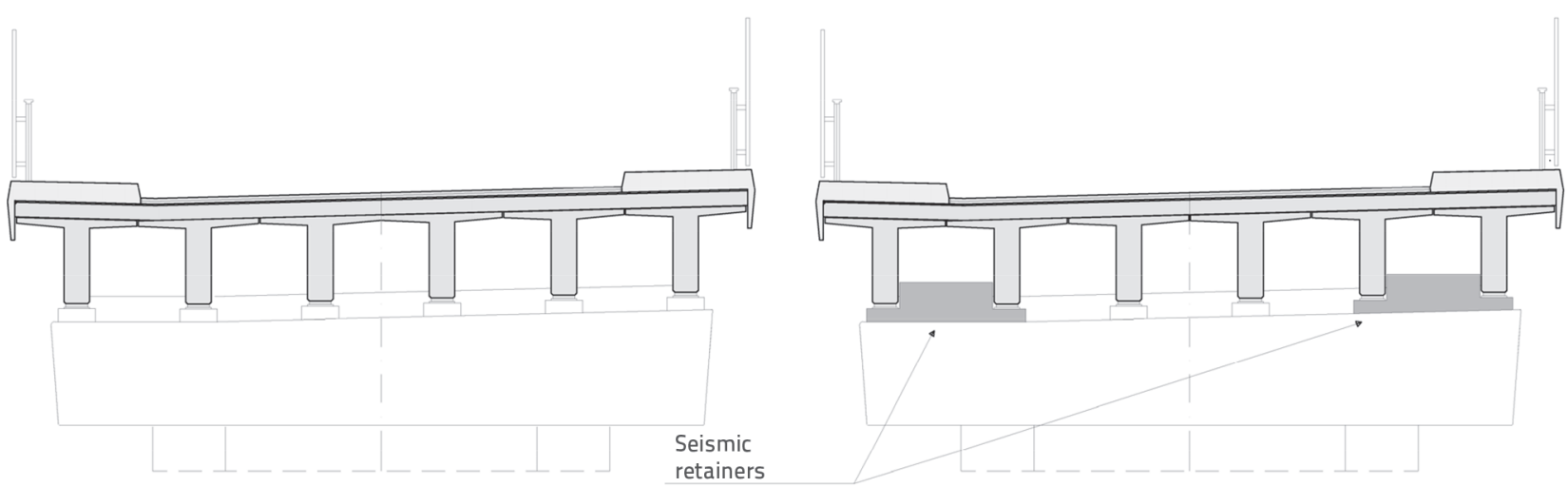

Figure 24. Girder bridge bearings without (left) and with (right) seismic retainers to prevent horizontal displacement (reproduced from [80]

they can prevent progressive collapse, while in other cases they can in fact initiate such collapse. These claims are justified by the fact that the propagation of progressive collapse requires continuity of the load-bearing elements although, in the case of the Ronan Point apartment building, the collapse was caused by the lack of continuity of reinforced concrete floor slabs. In the case of existing bridges, it is possible to remove expansion joints and bearings and create a monolithic structure, which is described as an integral bridge. This strategy is often used to reduce the ever increasing maintenance costs for bearings and expansion joints, and is justified for smaller bridges that are not subjected to large displacements, resulting in a more robust bridge structural system [82].

During the design process in which robustness is achieved through implementation of some of the strategies described in this section, it is important to take into account mutual interaction of these strategies, and optimization of the global structural system. These robustness elements are not mutually exclusive and, in fact, their combination is crucial for achieving adequate robustness. Therefore, during the design process, each structure should be considered as a unique system, and an optimum solution for achieving robustness should be selected based on engineering knowledge and expertise.

\section{Conclusions}

Despite considerable level of knowledge and experience, and design codes and guidelines that are applied during bridge design and construction, engineering mistakes are always possible, and extreme events may occur during the life span of bridges, which can all lead to structural failure. Furthermore, practical examples prove that inappropriate maintenance is often a problem in existing bridges which are in such cases subjected to unrestrained deterioration, increasing the risk of partial or complete collapse.

The aim of this paper is to

- present a comprehensive review of importance of forensic structural engineering during investigation of bridge failure events,

- offer a review and analysis of available data of bridge collapses worldwide in order to determine the frequency and influence of specific critical causes of collapse and, finally, to

- use the analysed data to present guidelines and recommendations (along with practical examples) for the design and maintenance of robust bridges, focusing on avoidance of progressive collapse.

Based on systematization of available bridge collapse data, it is clear that human factor has a major role in structural failure, meaning that a responsible approach to this issue and its subsequent resolution, could result in avoidance of potential catastrophic failures in the future.

Documentation of all bridge collapses with clearly determined causal connections, putting this documentation at the disposal of engineers and researchers worldwide, learning from past mistakes, improvement of design codes, and use of proper engineering approaches in practical implementation of such codes, should be an imperative objective in order to avoid similar mistakes in the complex process of bridge design, construction, and maintenance. 


\section{REFERENCES}

[1] National Academy of Forensic Engineers, https://www.nafe.org/, 2021, 1.3. 2021.

[2] ASCE, https://www.asce.org/forensic-engineering/forensicengineering/, 1.3.2021.

[3] Vykopalová, H., Cupal, M.: Forensic Engineering and the Importance of the Human Factor, Procedia - Social and Behavioral Sciences, 116 (2014), pp. 1665-1669

[4] Terwel, K., Ratay, R., Brühwiler, E., Wood, J., Godart, B., Dalmy, D.: An Initial Survey of Forensic Engineering Practices in Some European Countries and the USA, Forensic Engineering, 2012.

[5] Carper, K.L.: Forensic engineering, Second edition, CRC Press LLC, 37 (2001) 1.

[6] Terwel, K., Schuurman, M., Loeve, A.: Improving reliability in forensic engineering: The Delft approach, Proceedings of the Institution of Civil Engineers: Forensic Engineering, 171 (2018) 3, pp. 99-106

[7] Bennett, J., Brosz, H., Catania, J., Ellison, K., Maher, M., Porter, D., Pupulin, D., Thompson, C., Wilkinson, J., Veerasammy, R.: Forensic Engineering Investigations, 2016.

[8] Ahuja, D., Arya, B., Cohen, J., Dolhon, A., Dombrowsk, L., Hancock, D., Kardon, J.B., McCoy, K.L., Morse-Fortier, L.J., Nelson, E.L., Pack, I.L., Ratay, R.T., Rossell, C., Sonenthal, L.: Guidelines for Forensic Engineering Practice, 2012.

[9] Murphy, P.J., Duthie, L., Bielert, B., Charrett, D.: Australian legal guidelines for forensic engineering experts, Australian Journal of Structural Engineering, 11 (2020) 1, pp. 11-22, http://dx.doi.org/1 0.1080/13287982.2010.11465052

[10] Ratay, R.T.: An overview of forensic structural engineering, Structural Engineering International: Journal of the International AssociationforBridgeand Structural Engineering (IABSE), 27(2017) 3, http://dx.doi.org/10.2749/101686617X14881932437176.

[11] Ratay, R.T.: Forensic structural engineering handbook, Second Edition, 2010.

[12] ASCE: Code of Ethics Code of Ethics, 2017.

[13] Delić, E., Nukić, E.: Forenzički inženjering i upravljanje rizicima, Knjiga 2: Vođenje istražnih postupaka, Tuzla, 2014.

[14] Pearson, C., Delatte, N.: Collapse of the Quebec Bridge in 1907., Journal of Performance of Constructed Facilities, 20 (2006) 1, http://dx.doi.org/10.1061/(asce)0887- 3828 (2006) 20:1 (84).

[15] Ayub, M.: Pedestrian bridge collapse at university in Miami, Washington D.C., 2019.

[16] Calvi, G.M., Moratti, M., O'Reilly, G.J., Scattarreggia, N., Monteiro, R., Malomo, D., Calvi, P.M., Pinho, R.: Once upon a Time in Italy: The Tale of the Morandi Bridge, Structural Engineering International, 29 (2019) 2, pp. 198-217, http://dx.doi.org/10.1080/10168664.2 018.1558033.

[17] Burlando, M., Romanic, D., Boni, G., Lagasio, M., Parodi, A.: Investigation of the weather conditions during the collapse of the Morandi bridge in Genoa on 14 august 2018 using field observations and WRF model, Atmosphere, 11 (2020) 7, http:// dx.doi.org/10.3390/atmos11070724.

[18] Syrkov, A., Sizikov, A.: Enhancing of bridge management given failures data, IABSE Symposium, Synergy of Culture and Civil Engineering - History and Challenges, Wroclaw, 2020., pp. 11731180
[19] Garg, R.K., Chandra, S., Kumar, A.: Analysis of bridge failures in India from 1977 to 2017, Structure and Infrastructure Engineering, 2020, http://dx.doi.org/10.1080/15732479.2020.1832539.

[20] Tan, J.S.; Elbaz, K.; Wang, Z.F.; Shen, J.S.; Chen, J. Lessons Learnt from Bridge Collapse: View of Sustainable Management, Sustainability, 12 (2020), pp. 1205, https://doi.org/10.3390/ su12031205

[21] Choudhury, J., Hasnat, A.: Bridge collapses around the world: Causes and mechanisms, 2015.

[22] Tweed, M. H.: A summary and analysis of bridge failures, 1969.

[23] Pravilnik o kontroli projekata, (NN 32/14, 72/20), 2020.

[24] Pravilnik o upisu u razred revidenata, (NN 50/2020), 2020.

[25] Pravilnik o načinu provedbe stručnog nadzora građenja, obrascu, uvjetima i načinu vođenja građevinskog dnevnika te o sadržaju završnog izvješća nadzornog inženjera, (NN 111/2014,107/2015, 020/2017, 098/2019, 121/2019), 2020.

[26] Ruška, F., Dolaček-Alduk, Z., Dimter, S., Zagvozda, M.: Application of BIM technology in linear construction projects, $5^{\text {th }}$ International Conference on Road and Rail Infrastructure - CETRA 2018, Road and Rail Infrastructure V, (ed. Lakusic, S.), pp. 1469-1474, 17-19 May 2018, Zadar, Croatia, http://dx.doi.org/10.5592/co/ cetra.2018.917.

[27] HKIG: Opće smjernice za BIM pristup u graditeljstvu, Naklada Zadro, 2017.

[28] Hunt, C.A.: The Benefits of Using Building Information Modeling in Structural Engineering, 2013., pp. 31-37

[29] Imam, B.M., Chryssanthopoulos, M.K.: Causes and consequences of metallic bridge failures, Structural Engineering International: Journal of the International Association for Bridge and Structural Engineering (IABSE), 22 (2012) 1, pp. 93-98, http://dx.doi. org/10.2749/101686612X13216060213437.

[30] Giordano, P.F., Prendergast, L.J., Limongelli, M.P.: A framework for assessing the value of information for health monitoring of scoured bridges, Journal of Civil Structural Health Monitoring, 10 (2020) 3, pp. 485-496, http://dx.doi.org/10.1007/s13349-02000398-0.

[31] Eurokod: Osnove projektiranja konstrukcija, HRN EN 1990:2011; (EN 1990:2002 + A1:2005+ A1:2005/AC:2010)

[32] Arioli, G., Gazzola, F.: Old and new explanations of the Tacoma Narrows Bridge collapse, Atti XXI Congresso AIMETA, Torino, 2013., p. 10

[33] Green, D., Unruh, W.G.: The failure of the Tacoma Bridge: A physical model, American Journal of Physics, 74 (2006) 8, pp. 706-716, http://dx.doi.org/10.1119/1.2201854

[34] Olson D.W. et al.: The Tacoma Narrows Bridge collapse, Physics today, 68 (2016), pp. 64-65

[35] Peroš, B., Boko, I., Šimunović, T.: Analiza djelovanja vjetra na Dubrovački most, GRAĐEVINAR, 57 (2005) 2, pp. 87-94

[36] Eurokod 1: Djelovanja na konstrukcije - Dio 1-4: Opća djelovanja - Djelovanja vjetra, HRN EN 1991-1-4:2012, (EN 1991-1-4:2005+AC:2010+A1:2010)

[37] Setunge, S.: Failure mechanisms of bridge structures under natural hazards, 2018.

[38] Chen, W.F., Duan, L.: Earthquake Damage to Bridges, 2003. 
[39] Kulicki, J.M.: Learning from failures and mistakes - their influence on U.S. bridge codes and practice, XXV Konferencja Naukowotechniczna, 2011.

[40] Lee, G.C., Mohan, S.B., Huang, C., Fard, B.N.: A study of U.S. bridge failures (1980-2012), Technical Report MCEER -13-0008, 2013.

[41] Prendergast, L.J., Limongelli, M.P., Ademovic, N., Anžlin, A., Gavin, K., Zanini, M.: Structural health monitoring for performance assessment of bridges under flooding and seismic actions, Structural Engineering International, 28 (2018) 3, pp. 296-307, http://dx.doi.org/10.1080/10168664.2018.1472534.

[42] Mujkanovic, N., Vlašić, A., Šavor, Z.: Sanacija željezničkog mosta Sava Jakuševac, Dani prometnica 2012 - Građenje prometne infrastrukture (ed. Lakusic, S.), Građevinski fakultet Sveučilišta u Zagrebu, Zavod za prometnice, 2012, pp. 85-117

[43] Schumacher, J.: Assessment of Bridge-Structures Under Fired Impact: A Case Study Approach, 2016.

[44] Godart, B., Berthellemy, J., Lucas, J.P.: Diagnosis of a large steel bridge close to collapse during a fire, Engineering for Progress, Nature and People, 2014., pp. 1031-1038, http://dx.doi. org/10.2749/222137814814067293.

[45] Giuliani, L., Crosti, C., Gentili, F.: Vulnerability of bridges to fire, Bridge Maintenance, Safety Management, Resilience and Sustainability - Proceedings of the Sixth International Conference on Bridge Maintenance, Safety and Management, 2012., pp. 1565-1572, http://dx.doi.org/10.1201/b12352-225

[46] Eurokod 1: Djelovanja na konstrukcije - Dio 1-7: Opća djelovanja - Izvanredna djelovanja, HRN EN 1991-1-7:2012, (EN 1991-17:2006+AC:2010)

[47] Skokandić, D., Mandić Ivanković, A.: Value of additional traffic data in the context of bridge service-life management, Structure, and Infrastructure Engineering, 2020, 10.1080/15732479.2020.1857795

[48] Eurokod 1: Djelovanja na konstrukcije - 2.dio: Prometna opterećenja mostova, HRN EN 1991-2:2012/NA:2012, (EN 1991-2:2003+AC:2010)

[49] Skokandić, D., Mandić Ivanković, A., Žnidarič, A., Srbić, M. Modelling of traffic load effects in the assessment of existing road bridges, GRAĐEVINAR, 71 (2019) 12, pp. 1153-1165, https://doi. org/10.14256/JCE.2609.2019

[50] World Urbanization Prospects: The 2018 Revision, New York, USA, 2019.

[51] Gross, M.: A planet with two billion cars, Current Biology, 26 (2016) 8, pp. R307-R310, http://dx.doi.org/10.1016/j.cub.2016.04.019.

[52] Luechinger, P., Fischer, J.: JRC New European Technical Rules for the Assessment and Retrofitting of Existing Structures, Policy Framework, Existing regulations and standards, Prospect for CEN Guidance, 2015

[53] Liang, Y., Xiong, F.: Study on Fatigue Load Model of Highway Bridges: A Case in Southeast China, GRAĐEVINAR, 72 (2020) 1, pp. 21-33, doi: https://doi.org/10.14256/JCE.2664.2019

[54] Zakon o gradnji (NN 153/13, 20/17, 39/19, 125/19), 2019.

[55] Nasr, A., Björnsson, I., Honfi, D., Larsson Ivanov, O., Johansson, J., Kjellström, E.: A review of the potential impacts of climate change on the safety and performance of bridges, Sustainable and Resilient Infrastructure, 2019., http://dx.doi.org/10.1080/23789 689.2019.1593003.

[56] Brischke, C., Meyer-Veltrup, L.: Wood Protection by Design - Concepts for Durable Timber Bridges, $11^{\text {th }}$ Meeting of the Northern European Network on Wood Science and Engineering, Poznan, Poland, 2016
[57] Bjegović, D., Štirmer, N.: Teorija i tehnologija betona, Građevinski fakultet Sveučilišta u Zagrebu, 2015., p. 999

[58] Kušter Marić, M., Ivanković, A.M., Vlašić, A., Bleiziffer, J., Srbić, M., Skokandić, D.: Assessment of reinforcement corrosion and concrete damage on bridges using non-destructive testing, GRAĐEVINAR, 71 (2019) 10, pp. 843-862, https://doi. org/10.14256/JCE.2724.2019

[59] Zambon, I., Vidovic, A., Strauss, A., Matos, J.: Use of chloride ingress model for condition assessment in bridge management, GRAĐEVINAR， 71 (2019) 5， pp. 359-373, https://doi. org/10.14256/JCE.2411.2018

[60] FitzSimons, N.: Historical Perspective of Failures of Civil Engineering Works, 1986., pp. 38-45

[61] O'Connor, A., Enevoldsen, I.: Probability-based assessment of highway bridges according to the new Danish guideline, Structure and Infrastructure Engineering, 5 (2009) 2, pp. 157-168

[62] Baker, J.W., Schubert, M., Faber, M.H.: On the assessment of robustness, Structural Safety, 30 (2008) 3, pp. 253-267, http:/ dx.doi.org/10.1016/j.strusafe.2006.11.004.

[63] Starossek, U., Wolff, M.: Progressive Collapse: Design Strategies, 2005., pp. 9-16, http://dx.doi. org/10.2749/222137805796270829.

[64] Brett, C., Lu, Y.: Assessment of robustness of structures: Current state of research, Frontier of Structural and Civil Engineering, 7 (2013) 4, pp. 356-368, http://dx.doi.org/10.1007/s11709-0130220-z.

[65] Knoll, F., Vogel, T.: Design for Robustness, IABSE - IVBH ETH Zurich, Zurich, Switzerland, 2009.

[66] UFC 4-010-01: DoD Minimum Antiterrorism Standards for Buildings, Unified Facilities Criteria, 12 (2018), p. 91, http://www. wbdg.org/ffc/dod

[67] ASCE: Minimum design loads for buildings and other structures, ASCE Standard, 2005

[68] General Services Administration (GSA): GSA Progressive Collapse Analysis and Design Guidelines for New Federal Office Buildings and Major Modernizations Projects, 2003.

[69] Starossek, U., Haberland, M.: Disproportionate Collapse: Terminology and Procedures, Journal of Performance of Constructed Facilities, 24 (2010) 6, pp. 519-528, http://dx.doi. org/10.1061/(asce)cf.1943-5509.0000138

[70] Starossek, U.: Typology of progressive collapse, Engineering Structures, 29 (2007), pp. 2302-2307, http://dx.doi.org/10.1016/j. engstruct.2006.11.025.

[71] Aoki, Y.: Analysis of the Performance of Cable-Stayed Bridges under Extreme Events, 2014

[72] Seyed Khoei, A., Akbari, R., Maalek, S., Gharighoran, A.: Assessment of Design and Retrofitting Solutions on the Progressive Collapse of Hongqi Bridge, Shock and Vibration, 2020, http://dx.doi. org/10.1155/2020/4932721.

[73] Bi, K., Hao, H.: Progressive collapse analysis of Hongqi Viaduct: A multi-span simply- supported Bridge, Australia Earthquake Engineering Society Conference, 2013., http://www.aees.org.au/ wp-content/uploads/2015/06/15-Bi-Kaiming-Progressive.pdf.

[74] Davis-Mcdaniel, C.: Fault-Tree Model for Bridge Collapse Risk Analysis, 2011., p. 85

[75] Čizmar, D., Rajčić, V., Kirkegaard, P.H., Sorensen, J.D.: Probabilistic analysis of structural robustness, GRAĐEVINAR, 63 (2011) 5, pp. 431-439 
[76] Duncan, S., Callaway, M., Newman, E.J., Steven, H., Duncan, J.W.: Network Robustness and Fragility: Percolation on Random Graphs, Physical review letters, 85 (2000), pp. 5468, 85, http:// dx.doi.org/doi.org/10.1103/PhysRevLett.85.5468.

[77] JCSS: Probabilistic Model Code - Part 1, JCSS, 2001, p. 65

[78] Starossek, U.: Progressive collapse of bridges-Aspects of analysis and design, International Symposium on Sea-Crossing Long-Span Bridges, Mokpo, Korea, 2006.

[79] Šavor, Z., Mujkanovic, N., Hrelja Kovacevic, G., Bleiziffer, J.: Reconstruction of the Pag Bridge, Chinese-Croatian Joint Colloquium - Long Arch Bridges, SECON HDGK, 2008, pp. 241252
[80] Hrelja Kovačević, G., Mandić Ivanković, A.: Assessing seismic vulnerability of existing bridgesusing fragility curves, $6^{\text {th }}$ Symposium on Doctoral Studies in Civil Engineering, University of Zagreb, Faculty of Civil Engineering, 2020., pp. 163-174, http:// dx.doi.org/doi.org/10.5592/CO/PhDSym.2020.13.

[81] Misini, M., Ristic, J., Ristic, D., Guri, Z., Pllana, N.: Seismic upgrading of isolated bridges with SF-ED devices: Analytical study validated by shaking table testing, GRAĐEVINAR, 71 (2019) 4, pp. 255-272, doi: https://doi.org/10.14256/JCE.2274.2017

[82] Šavor, K.: Integral bridges, GRAĐEVINAR, 55 (2003) 9, pp. 519525 